\title{
SPOUSAL HEALTH SHOCKS AND THE TIMING OF THE RETIREMENT DECISION IN THE FACE OF FORWARD-LOOKING FINANCIAL INCENTIVES
}

\author{
Courtney Harold Van Houtven and Norma B. Coe
}

CRR WP 2010-7

Date Released: June 2010

Date Submitted: June 2010
Center for Retirement Research at Boston College
Hovey House
140 Commonwealth Avenue
Chestnut Hill, MA 02467

Tel: 617-552-1762 Fax: 617-552-0191

Courtney Harold Van Houtven is a research scientist at the Durham VA and an assistant professor at Duke University Medical Center. Norma B. Coe is a research economist at the Center for Retirement Research at Boston College. The research reported herein was pursuant to a grant from the U.S. Social Security Administration (SSA) funded as part of the Retirement Research Consortium (RRC). The findings and conclusions expressed are solely those of the authors and do not represent the views of SSA, any agency of the Federal Government, the RRC, the Center of Excellence in Health Services Research in Primary Care, Durham Veterans Affairs Medical Center, Duke University Medical Center, or Boston College.

(C) 2010, by Courtney Harold Van Houtven and Norma B. Coe. All rights reserved. Short sections of text, not to exceed two paragraphs, may be quoted without explicit permission provided that full credit, including $(\subset$ notice, is given to the source. 


\begin{abstract}
About the Sandell Grant Program
This paper received funding from the Steven H. Sandell Grant Program for Junior Scholars in Retirement Research. Established in 1999, the Sandell program's purpose is to promote research on retirement issues by scholars in a wide variety of disciplines, including actuarial science, demography, economics, finance, gerontology, political science, psychology, public administration, public policy, sociology, social work, and statistics. The program is funded through a grant from the Social Security Administration (SSA). For more information on the Sandell program, please visit our web site at http://crr.bc.edu/opportunities/steven_h._sandell_ grant_program_2.html, send e-mail to crr@bc.edu, or call Marina Tsiknis at (617) 552-1092.
\end{abstract}

\title{
About the Center for Retirement Research
}

The Center for Retirement Research at Boston College, part of a consortium that includes parallel centers at the University of Michigan and the National Bureau of Economic Research, was established in 1998 through a grant from the Social Security Administration. The Center's mission is to produce first-class research and forge a strong link between the academic community and decision makers in the public and private sectors around an issue of critical importance to the nation's future. To achieve this mission, the Center sponsors a wide variety of research projects, transmits new findings to a broad audience, trains new scholars, and broadens access to valuable data sources.

\author{
Center for Retirement Research at Boston College \\ Hovey House \\ 140 Commonwealth Avenue \\ Chestnut Hill, MA 02467 \\ phone: 617-552-1762 fax: 617-552-0191 \\ e-mail: crr@bc.edu \\ crr.bc.edu
}

Affiliated Institutions:

The Brookings Institution

Massachusetts Institute of Technology

Syracuse University

Urban Institute 


\begin{abstract}
A long and still growing strand of the retirement literature examines the role financial incentives play in the timing of the retirement decision. A more recent second strand of work has focused on the role of health shocks in the retirement decision. This paper combines these two components of the literature in order to measure the marginal impact of current wealth (including pension accrual), forward-looking financial incentives (peak-value pension wealth), and health shocks on married individuals' retirement decision. This paper helps to clarify whether previously omitted forward-looking financial incentives can explain the strong role attributed to health shocks in the retirement decisions of married couples. We find that financial incentives are the most important determinant of retirement behavior empirically. A husband is about half as responsive to his wife's financial incentives as he is to his own. Interestingly, we find that married men are responsive to their wives' health shocks, on both the intensive and extensive margin, but find wives' decisions concerning work are largely unaffected by their husbands' health shocks.
\end{abstract}




\section{Introduction}

Understanding the retirement decision has long been of interest to economists. The earliest literature focused on the role financial incentives embedded into Social Security and defined benefit plans played in the retirement decisions of men. Much has changed in the labor market since then, and the literature has followed. Recent work has expanded the financial influences studied, by including the availability of retiree health insurance or early retirement windows, and non-financial considerations, namely health and stress levels. Additional work has focused on modeling the retirement decision of women and married individuals as a joint decision. However, to date there has not been a comprehensive study that includes financial, health, and spousal considerations in one model of retirement.

This paper aims to answer two main research questions: What is the relative importance of spousal health shocks and financial incentives in the retirement decision of married men and married women, compared to one's own health and financial incentives? It is important to know the relative importance of each of these considerations to know whether previously omitted financial incentives can explain the strong role attributed to health shocks in the retirement decisions of coupled individuals, or vice versa. Second, we aim to identify what types of health shocks have the most influence on the retirement decisions of individuals in married couples, and whether those differ by age, gender, or health insurance status. Beyond the ability to manage work with caregiving responsibilities, a spouse’s health shock may alter one’s expected retirement age if it changes the expected life expectancy of the spouse, or expectations about quality of years of remaining life together. This type of wake-up call, for lack of a better term, may lead a person to decide to forgo the extra retirement benefit accrual to consume more leisure together. 
This paper will also help inform public policy. Only when both the financial and health reasons are included in a parsimonious model of retirement can one predict the full impact and cost of various public policy options. For example, the full retirement age to receive Social Security will increase from 65 to 67 by 2027 and impact retirement behavior. The effectiveness of this change on increasing the retirement age is uncertain, but plays a central role in estimating the funding status of the program. If access to health insurance has a large impact on the retirement decision, a universal health insurance program could also have large financial implications for the Social Security program. Further, if medical advances mean preservation of the ability to work, then older workers may delay retirement and continue to contribute to the growth of the economy, which should be considered in cost-benefit analysis of health care advancements.

\section{Financial Incentives and Retirement}

There is a large literature dating back to the 1970s that tries to measure the relationship between retirement benefits and labor force participation (for a review, see Coile and Gruber, 2007). The general conclusion from the early work was that Social Security has had an important, but modest, impact on retirement behavior. Samwick (1998) and Stock and Wise (1990) emphasize that there is an important tradeoff in the retirement decision: the level of retirement benefits and the entire future potential income and wealth stream from working. This option value model states that retirement models should include the utility difference between retiring today and retiring at the date that optimizes utility. Coile and Gruber (2007) concur that forward-looking pension incentives are essential in retirement models. They argue, however, that a different measure is necessary, since wages and tastes for work are most likely correlated, 
and thus variation from wages is not something one would ideally use to identify differences across individual retirement choices (this point was first highlighted in Krueger and Pischke, 1992). Coile and Gruber carefully show that peak-value incentive calculations, the difference between Social Security benefits if one retires today versus when one retires when their benefits are maximized, perform better than the option value approach for Social Security benefits. They also counter the earlier literature and find that individuals are just as responsive to Social Security incentives as to private pension plans.

Previous research has shown that defined benefit pension plans typically incorporate incentives that encourage early retirement. For example, Friedberg and Webb (2005) estimate that, on average, employees in defined benefit plans retire about two years earlier than otherwise similar employees in defined contribution plans. Brown (2009) examines the California teachers' pension plan and finds that an unexpected rise in the price of retirement has a positive, but relatively small effect on the fraction of people retiring later. The implied estimates of the elasticity of retirement age with respect to the price of retirement are 0.02 in the medium-run and 0.10 in the long-run. Alva, Coe and Webb (2010) find that changing these incentives to retire early has a large impact on the retirement age. Simply allowing individuals to place their retirement benefits in an interest-bearing account and remain working for up to four years lead municipal workers to increase their retirement age by approximately 14 months, on average.

As women's labor force participation has grown, so has the literature examining their retirement decisions. Honig (1998) focuses on married women’s retirement expectations and the role their own financial incentives play in that expectation Using the Health and Retirement Study (HRS), she finds that the husband's retirement plans, the enjoyment of joint leisure, the wife's current wage, employer-sponsored health and disability insurance characteristics, and the 
wife's pension eligibility characteristics are important in the expected retirement hazard for women working full-time between the ages of 51-61. However, her own Social Security benefits appear irrelevant in the retirement expectation, which could be because she would claim on her husband's benefits and not her own, or lack of familiarity with the Social Security benefit formula.

Hurd (1990), Gustman and Steinmeier (2000), and Maestas (2001) build structural models of the joint retirement decision. A fundamental assumption needed in this literature concerns how to model the interaction between husbands and wives. Maestas (2001) adds the additional dimension of leisure complementarity and finds it is an important component in explaining the near-simultaneous retirement pattern that is observed in the data, despite differences in age. Taking a reduced-form approach, Johnson and Favreault (2001) find that retirement of one spouse is likely to lead to the retirement of the other, unless health reasons caused the first retirement. This could be taken as evidence of the added-worker effect, where spousal employment acts as a type of insurance for the other spouse's income. The addedworker effect could be especially strong when the spouse is not yet eligible for Social Security benefits. Coile (2004b) examines the relative importance of one’s own and one's spouse's financial incentives when modeling married household retirement decisions. She finds that women and men respond similarly to their own incentives but that only men respond to their wives’ financial incentives.

\section{Health Shocks and Retirement}

Another strand of the literature examines how health, and health shocks, impact the decision to work at later ages. First, bad health may make work difficult or impossible, and 
second, health shocks may provide information on healthy-life expectancy, inducing earlier retirement in order to enjoy remaining healthy leisure time. However, spousal health shocks could impact the working decision in either direction. The desire for joint leisure time or caregiving responsibilities may induce early retirement for both members of a couple, or the added-worker effect may induce a spouse to actually work longer in the face of a spousal health shock, with one spouse acting as informal insurance for the foregone wages of the other spouse. Coile (2004a) found that one’s own acute health shocks, particularly those associated with significant loss of functioning, were associated with increased odds of leaving the labor force, and that the effect for men was greater than for women. The response to a spousal health shock, by contrast, was much smaller. Women reduced their labor supply modestly if a husband had a health shock that was associated with a significant loss of functioning, whereas men slightly increased their labor supply. In a study of the effect of health on retirement expectations, McGarry (2004) found that changes in health were much more important than changes in income or wealth in affecting the expected timing of one's own retirement. Both of these estimates suffer from a potential omitted variable bias, since the financial incentives for retirement were not included in the model. By examining health shocks and forward-looking financial incentives in one model, we will estimate the relative contribution of each to the retirement decision.

The definition of health shocks can be quite varied, and the appearance of new chronic conditions may have a very different effect on work behavior than an acute health shock. The onset of diabetes, for example, would require one member of a couple to adapt to dietary, medication, and medical care demands, but should not generally entail huge time demands for the spouse compared to an acute health shock. Yet even among acute health shocks, depending on the recovery period, there may be very different pressures on a spouse to hire help in the 
home, to provide informal care, and thus to juggle work responsibilities. For example, a new cancer diagnosis of one's wife might lead to short-term disruption to the husband's working life—contained during the cancer treatment and recovery period—likely less than one year. This type of a shock may be accommodated without much work disruption through formal workplace policies such as the Family and Medical Leave Act, or informal arrangements with bosses, adult children, or other informal support systems. By contrast, a new major stroke experienced by one's husband could have wildly different ramifications, with longer periods of recovery, care demands, purchases of in-home health care, and substantial work disruption. For married couples, the informal care demands could be considerable, and may even replace the hiring of home health care workers (Van Houtven, Taylor, Steinhauser, and Tulsky, 2009). Therefore, with severe and lingering health shocks, work disruption may be very extensive.

Gender, age, and age differences between spouses may influence how a spousal health shock affects work. Women may have lower attachment to the labor market, or could be younger than their husbands, hence face an increased likelihood that their spouse will experience a health shock. There is some evidence that women claim Social Security benefits too early already (Munnell and Soto, 2007), yet it is unclear how health shocks to husbands contribute to this phenomenon. Disability risk increases with age and some health shocks will be most likely to occur to the older member of a couple first. The younger spouse may not retire earlier due to health shocks of the older member, however, since she might be facing a longer-than-anticipated lifespan without the earnings of the older member of the household.

Finally, health and long-term care insurance are key factors to control for when measuring the work response to health shocks. There is a lengthy literature on the impact of health insurance on job mobility in general (for a review, see Gruber and Madrian, 2002), and if 
only one member has employer-sponsored insurance available to them, this can act as a significant factor in job-lock (Gilleskie and Blau, 2006; McClellan, 1998). What has not been explored yet is the role of private long-term care insurance. By purchasing long-term care insurance, the couple covers both the financial risk of a debilitating health shock, but also the need for extensive informal care from the spouse. We explore whether or not those who have their formal long-term care needs insured have different responses than those who do not.

In light of these important factors, we control for age and age differences, as well as insurance availability and coverage, and examine men and women's decisions separately. Further, we examine a broad range of health shocks: new acute events such as heart attacks, new stroke, new cancer (McClellan, 1998), and new chronic conditions, as well as broader measures of shocks such as new functional limitations (Coile, 2004a) and inpatient hospitalization of one's spouse (Christakis and Allison, 2006). We analyze if the duration of the recovery period after the health shock impacts one's labor force decisions.

\section{Data}

Using eight waves (1992 to 2006) of the Health and Retirement Study (HRS), as prepared by RAND, linked to Social Security Administration (SSA) data. Using linked HRS-SSA data provides the distinct advantages of minimizing measurement error on work behavior and pension earnings while affording the use of a rich set of health information for both members of the couple. We will examine new acute events such as heart attacks and new cancer diagnoses (McClellan, 1998) as well as broader measures of shocks such as new functional limitations (Coile, 2004a) and inpatient hospitalization of one’s spouse (Christakis \& Allison, 2006). 
Sample. The analyses are performed separately for male workers and female workers. We look at two-year transitions from work to retirement (between $t$ and $t+2$ ). To be included in the sample, an HRS respondent had to be married continually to the same person, working for pay in the year they enter the survey (1992 or 1998), be between the ages of 50 and 69 and have spouses between the ages of 40 and 69 . The sample is further limited to persons born in or after 1922 due to changes in the Social Security benefit formula (Coile and Gruber, 2007). In addition, an individual had to appear at least for two consecutive waves (to create the health shock variables). We eliminate persons who had ever applied for disability insurance because their labor attachment may be very different from non-disabled workers. We also eliminate the self-employed from the analysis because their work hours and retirement flexibility may be very different than individuals employed by others. Finally, once a person retired, we assume it is an absorbing state, and following the approach of Johnson and Favreault (2001), Coile (2003), and Coile and Gruber (2007), we keep persons in the sample only for the wave in which they retire. Thus, we only have one observation for a person in the state of retirement.

Table 1 shows the sample attrition. In addition to our established sample selection criteria, there were cases where earnings were missing (from both Social Security Administration Data and earnings in the RAND variables). Therefore, we further eliminated persons who had missing earnings or missing PDV (13\% or so of men and just under 6\% for women). Spouses of eligible workers may or may not have been working. Therefore, there are households that contribute to the male sample but not the female sample, and vice versa.

From the original full HRS cohort for 1992-2006, or 56,339 men-waves and 76,037 women-waves, 8,447 man-wave observations and 6,854 woman-wave observations met our inclusion criteria. This corresponds to 3,357 men and 3,448 women. The fact that there are 
slightly fewer men than women but more man-wave observations means that women attrite from the sample at a faster rate (either due to retirement, loss at follow-up, divorce/death of spouse, or own death).

\section{Measures.}

Dependent Variables.

We define retirement as people both reporting that they were retired and not working for pay, consistent with Coile and Gruber (2007). We also look at changes in hours worked in the past year to examine whether there existed gradual reductions in work or bridges to retirement based on health shocks or other factors (Ruhm, 1990). We measure change in hours as the change in hours worked per week in the last period. ${ }^{1}$

Explanatory Variables.

Financial incentives. The models control for the expected present discounted value (PDV) of Social Security wealth of the couple, using a 3\% discount rate. The preferred forwardlooking financial incentive is peak value, because it has been shown to be the best predictor of retirement over other incentive calculations (Coile and Gruber, 2007). To calculate PV, we first estimate the PDV of retirement wealth at all possible retirement ages between 62 and 70 (if someone is under age 62, we assume they retire at age 62). We calculate this separately for the husband and the wife. The PV is the difference between the maximum PDV of benefits and the PDV of benefits today. ${ }^{2}$ By also including the annual salary the last full year the individual worked (EARN), this helps decouple the incentive measure from wages (Coile and Gruber,

\footnotetext{
${ }^{1}$ To account for the fact that there may be small or large adjustments to work due to health shocks, we also looked at the likelihood of reducing one's hours by more than five hours a week in addition to the continuous measure of change in hours (results available upon request).

${ }^{2}$ In order to make this calculation, we assume when the spouse would retire. See Appendix A for more details.
} 
2007). ${ }^{3}$ The model also controls for the present discounted value of private defined benefit pension wealth (see Appendix B for more detail), and defined contribution wealth (see Appendix C for more details). Rounding out the financial variables, the models control for liquid asset quartiles (with the lowest quartile as the reference) and net worth quartiles (lowest as reference).

Health shocks. Unanticipated health shocks range from mild to severe; we expect the retirement effects to be increasing in the severity of the health shock. In general we discern between new chronic conditions, new acute conditions, and new mental health conditions in order to define a health shock. Because some of the health shock questions are worded, "Whether you ever were told to have these conditions," we code a health shock as such only when it did not exist in the previous wave. We expand upon Coile's (2003) definition of acute and chronic shocks based on current literature and clinical input. Therefore, the compilation variable for acute health shock had a value of 1 if any of the following new conditions occurred: new heart attack, new stroke, or new cancer, and zero otherwise, which is consistent with Coile's (2007) definition. Chronic health shocks are coded as such if a person had new diabetes, new heart failure, new angina, new high blood pressure, new arthritis, or new incontinence. Mental health shocks $(0,1)$ include having a new CESD-8 score above 4 or a new psychological or emotional problem ("Have you ever had or has a doctor ever told you that you have any emotional, nervous, or psychiatric problems?”).

In addition, we control for any injuries in the last period, defined as a fall requiring medical attention, a hip fracture, or an accident that caused a recent health problem, as well as existence of new significant pain (“Are you often bothered by pain?”). The pain is a proxy for low back pain, due to the established link between low back pain and work absences (Stewart,

\footnotetext{
${ }^{3}$ Average indexed monthly earnings (AIME) is not included directly in the model because of its high correlation with $\operatorname{PDV}(\rho=0.95)$.
} 
Ricci, Chee, Morganstein, and Lipton, 2003). Following work by Christakis and Allison (2006) who found that having a spouse visit a hospital in one year significantly increased one's mortality risk in the next year, we control for inpatient hospitalization of oneself and one's spouse. We distinguish between short inpatient stays (one night only) and longer inpatient stays to account for observational visits and more intensive and potentially invasive or serious inpatient stays (two or more nights). Because some of the health shocks may be highly correlated, such as heart attack and an inpatient hospitalization, we carefully test for multicolinearity in the model.

Baseline health. We control for both subjective and objective measures of baseline health, because both appear to affect individual's expectations about retirement (McGarry, 2004). Due to the possibility of justification bias from including subjective health, we create a predicted value of self-rated health in the first wave we observe an individual, using an ordered probit model (Erdogan-Ciftci, Van Doorslaer, and Lopez-Nicolas, 2008). The results are listed in Appendix Table 1. Results are robust to whether or not the self-rated probability of living to age 75 is included in the model (results available upon request).

Age. A full set of age dummies (age 51 is reference), as well as differences in age between the husband and wife are included in the model.

Demographics. The models control for education (some college, college, missing education, with high school or under as the reference category), race (White, Black, Race Missing, with White being the reference category), and Hispanic ethnicity. Job tenure, potential job experience (squared, cubed and quadratic terms in some specifications), union membership status, and a missing indicator for union status are also be included. 
Health and long-term care insurance. We carefully control for insurance coverage and access to employer-sponsored health insurance, as well as being uninsured. We account for whether coverage from an employer-based plan comes from the respondent or the spouse. We measure the health insurance profile of the person at the time of the survey until the year they retire, at which time we measure health insurance as the health insurance they had in the last wave in which they were working. As such, the prevalence of Medicare, Medicaid, Veterans Affairs, and other governmental insurance is very low (around 12 percent overall), thus we combine them into one category of public insurance in the models. Having no insurance is the reference category.

In sensitivity analyses, we examine whether the presence of long-term care insurance for one's spouse affects an individual's retirement decision in light of a spousal health shock (limiting the sample to 1996 and beyond due to data problems (Finkelstein and McGarry, 2006)).

\section{Methodology}

We use a reduced form modeling approach that includes own and spousal health and financial incentives. We estimate the following equation, integrating financial incentives and health shocks in couples' retirement decisions:

$$
R_{h, t}=\beta_{0}+\beta_{1} F_{c, h, t}+\beta_{2} H S_{h, t}+\beta_{3} \hat{H}_{h, t-1}+\beta_{4} X_{h, t}+\beta_{5} F_{w, t}+\beta_{6} H S_{w, t}+\beta_{7} \hat{H}_{w, t-1}+\beta_{8} X_{w, t}+\gamma_{t}+e_{h, t}
$$

where $R_{h t}$ indicates whether the worker retires in that wave. The subscripts $h$ and $w$ refer to the husband and wife, respectively, while $c$ stands for couple. We also estimate the model separately for wives $\left(R_{w t}\right) . F$ is the financial information, which include the present discounted value of 
the Social Security wealth of the couple (c) (PDV), ${ }^{4}$ the peak value of Social Security for each individual (i) $(P V)$, last period's annual salary (EARN), net wealth and liquid asset quartile dummies. $H S$ is the vector of an individual's health shock measures, $\hat{H}$ is the individual's predicted baseline health. $X$ is a vector of demographic characteristics, union membership, job tenure, and experience. $y$ is a vector of time dummy variables. Non-linearities in the Social Security benefit and variation by age in peak values and accrual help identify the model. All standard errors are robust and clustered by the individual to account for repeated observations.

In addition to the probit model of the likelihood of retirement, we examine a regression model on change in hours among remaining workers, as well as the hazard of retirement at a given age, based on whether or not one controls for financial incentives, health shocks, a spouse's financial incentives, and a spouse's health shocks.

\section{Results}

Descriptive results.

A significant proportion of the sample retired at some point in the panel, $35.8 \%$ of husbands and 28.8\% of wives (Table 2). The husbands and wives had very similar PDV, around $\$ 35,000$ each. The peak value of the husband's Social Security retirement wealth was $\$ 14,000$ higher than wives on average, at \$78,000. Private defined benefit expected PDV was approximately one-fifth of expected Social Security PDV for husbands on average, at around $\$ 70,000$; it was substantially lower than this for wives, at just under $\$ 54,000$. The defined contribution wealth for men was twice that of wives in the sample (\$32,000 vs. $\$ 15,000)$, and annual earnings were similarly higher, at $\$ 46,000$ for husbands and $\$ 29,000$ for wives.

\footnotetext{
${ }^{4}$ Individual measures of Social Security PDV have been shown to be highly correlated (Coile 2004a), thus we calculate it for the couple together.
} 
Household net worth of the sample of wives was slightly higher than for husbands (to be in the sample you had to work but your spouse did not, so the two samples are unbalanced).

Recognizing that to be in the sample individuals were healthy enough initially to be in the labor force the first time they were observed; Table 2 shows that this sample experienced a significant number of health shocks while they were in the panel. Men had a higher proportion of acute health shocks, mainly attributed to heart attacks or infarction, at $15 \%$ versus $9.4 \%$ for the sample of wives. The health shock is defined as equal to one if they ever had that type of shock while observed in the sample (1994 to 2006). Therefore, 7.7\% of men had a new heart attack at some point while they were in the sample. The onset of new chronic conditions (at $57.3 \%$ for husbands and $60.9 \%$ for wives) and injuries (4\% for both samples) was remarkably similar. Wives had a higher rate of mental health problems, at $23.1 \%$ compared with $10 \%$ for the husband sample. A higher proportion of husbands had a hospital stay at some point, 36.8\% versus $31.5 \%$ in the wives sample.

The health insurance variables presented in Table 2 are measured the first time the person entered the sample. A higher proportion of the husbands (80\%) had insurance through their own job, whereas $57 \%$ of the wives had insurance through their own job.

\section{Main results.}

In Tables 3 and 4 we present four models separately for men and women. Model 1 is a retirement probit that controls for one’s own financial incentives; Model 2 adds one's own health shocks; Model 3 adds one’s spouse’s financial incentives (private pension and earnings); and Model 4 adds the spouse's health shocks. All four models also control for all of the variables described in the Methodology section. In the discussion of the results, we focus on the fully 
adjusted models for men and women, or Model 4, since the point estimates are fairly consistent across all models. This consistency is in itself an interesting result; it suggests that previous estimates that measure the impact of financial incentives/health on retirement, without adding the other to the model, could indeed be unbiased estimates.

Husbands.

Financial incentives. By far, one's own and the couple’s financial incentives are the most important determinants of a husband's retirement in a model fully controlling for financial incentives and health (Table 3). Consistent with findings by Coile and Gruber (2007), who focus on controlling for an exhaustive list of financial variables (but not health), we find that current earnings and wealth, as well as public and private retirement incentives, are important contributing factors to the retirement decision. An increase in the peak value of Social Security wealth by $\$ 10,000$ reduces the probability of retirement by just under 1 percentage point (Table 3, column 4). Having a higher present discounted value of retirement wealth, both in Social Security and defined benefit plans, is associated with an increase in retirement. The marginal effect of an additional \$10,000 dollars of annuity benefit, either in Social Security or DB plans, is identical ( $\mathrm{dy} / \mathrm{dx}=.0002$, or .02 percentage points). Defined contribution wealth is significant in Models 1 and 2 but not once you control for the spouse's characteristics. Furthermore, having higher earnings reduces the probability of retiring (a \$10,000 increase in earnings reduces the likelihood of retiring by 4.6 percentage points); being in the highest net worth or asset quartiles makes one less likely to retire compared with persons in the lower three quartiles. For example, husbands in the lowest net worth quartile are 3 percentage points less likely to retire than husbands in the highest quartile, all else constant. 
The wife's retirement wealth also influences a husband's retirement decision, although the marginal effect ( $\mathrm{dy} / \mathrm{dx}=.0001$ for a $\$ 10000$ increase in expected PDV) is half as much as for a man's own expected PDV; a wife's higher earnings make husbands less likely to retirement, but this effect is only one-quarter as strong as the response to his own earnings.

Health shocks. An acute health shock for husbands, that is, a new cancer diagnosis, a new heart attack or a new stroke, leads to a 2.2 percentage point increase in the likelihood of retirement. One additional limitation in activities of daily living (ADLs) leads to a 1.3 percentage point increase in the likelihood of retiring.

The only spousal health shock that impacts the husband's retirement hazard is a long hospitalization (defined as a greater than one night stay in the hospital in the two-year recall period of the survey), which increases the risk of retirement by 1.5 percentage points.

Having health insurance through one's wife's job increases the chance of retirement for husbands by $2.4 \%$ compared with having no insurance. Having insurance through one’s own job does not influence the chance of retirement compared with the uninsured, although the negative sign is consistent with expectations. Finally, working at a place that offered retiree health insurance increases the chance of retiring by 1.2 percentage points. Having a long tenure on the job and being a union member also increases the retirement risk by a small amount each.

Wives.

Financial incentives. The financial incentive profiles of women have a similar effect on retirement as husbands, with some differences in the magnitudes of the effects. A higher peak value of retirement wealth (e.g., an increase of $\$ 10,000$ ) reduces the odds of a wife's retirement by 0.5 percentage points, which is smaller in magnitude than for men ( 0.8 percentage points). However, the responsiveness to private $\mathrm{DB}$ wealth is identical between the genders 
(dy/dx=0.0002). An additional $\$ 10,000$ in expected PDV increases the odds of a woman retiring by .03 percentage points, which is about $50 \%$ higher than the finding for husbands. Defined contribution wealth is only significant at the $10 \%$ level for women, but also increases the chance of retirement slightly (dy/dx=.0001 for a $\$ 10,000$ increase in DC wealth). Annual earnings have two times the effect on retirement for women than for husbands, with an increase in annual earnings by $\$ 10,000$ reducing the chance of retirement for wives by 9.2 percentage points.

A husband's financial incentives also matter for the wife. In fact, a husband's expected DB wealth has almost twice the effect on his wife's retirement behavior than a wife's DB PDV has on her husband's retirement behavior. The husband's defined contribution wealth did not matter.

Health shocks. For working wives, the only health shock that influences the retirement decision was experiencing a significant injury (fall, hip fracture or accident that resulted in a health problem). Having an injury increases the likelihood of a wife retiring by 3.7 percentage points compared with wives who did not have an injury. Not a single spousal health shock influences a wife's likelihood of retiring.

Retirement hazard.

We estimate Weibull hazard models of the time until retirement to see if the same factors that predict discrete retirement predict time elapsed until retirement (Table 5 for men, Table 6 for women). ${ }^{5}$ This model is pared down of some variables because it is more difficult for hazard models to converge with large numbers of variables.

We find similar results to the discrete retirement model, with a few exceptions, namely, that PDV for husbands and wives does not influence the time to retirement, higher defined

\footnotetext{
${ }^{5}$ The results from a Cox proportional hazard model were very similar.
} 
contribution pension wealth significantly increases the risk of retirement and, spousal health shocks now significantly affects the risk of retirement for wives, but not as strongly for husbands. This is in direct contrast to the discrete case.

Other financial incentives continue to be very important determinants of time until retirement and are quite consistent across models one through four (Table 5 for husbands, Table 6 for wives). A higher PV reduces the risk of retirement for men and women (hazard ratio=.82 for men and .93 for women), thus, a higher PV makes people wait longer to retire. The same is true for earnings. An additional \$10,000 in one’s own earnings makes husbands $12 \%$ less likely to retire (Table 5, column 4) and women 20\% less likely (Table 6, column 4). One’s spouse’s earnings do not change the time until retirement. This is in contrast to private defined benefit PDV and defined contribution wealth in which the same dollar increase would lead to a slightly higher risk of retirement (less time elapsed until $t=$ retirement), by a small amount, about $0.2 \%$ to 0.3\% depending on the sample and variable (see Tables 5 and 6). Of the spouse's financial variables, only the spouse's DC wealth matters. For the husband sample, the magnitude of the effect is about the same as his own DC (0.3\% increase in retirement risk), but for wives, their husband's DC wealth is three times as high as the hazard ratio on her own DC (0.6\% increase in retirement risk).

Regarding one's own health shocks, for husbands, having a new limitation in activities of daily living (ADLs) hastens retirement. An additional ADL limitation is associated with a 20\% increase in the hazard of retiring. For women, having a new ADL injury also hastens retirement (by 50\%, one of the largest health magnitudes), whereas having a new IADL limitation reduces the risk of retirement, by $22 \%$. 
As mentioned, the role of spousal health shocks is markedly different in the hazard model than in the probit model of the retirement decision. For husbands, if the wife has an acute health shock (new heart attack, new cancer, or new stroke), the man is actually $25 \%$ more likely to work longer before retiring (although this effect is only significant at the $8 \%$ level). For wives, there are conflicting spousal health effects. If the husband experiences a new chronic condition, the wife retires $16 \%$ faster than if the husband has no new chronic condition $(\mathrm{p}=.053)$, and yet, if a husband has a short hospital stay, the wife is more likely to retire later, by about $30 \%$ compared with a wife whose husband has had no hospital stay.

Graphing the hazard functions across a few financial and health variables of interest helps illustrate the magnitude of the changes in the retirement hazard. In Figures 2-9, the y axis signifies the hazard ratio, while the $\mathrm{x}$ - axis represents age.

Comparing the hazard curve for different values of annual earnings shows that higher earners remain working for longer than lower earners (Figure 2 for husbands, Figure 6 for wives). The lowest earning profile (around $\$ 15,000$ ) is the top curve, meaning the rate of retirement was highest among this group, compared with the lowest curve, with earnings of around $\$ 100,000$. For women, the difference is similar across earnings groups (Figure 6). Being covered by a spouse's health insurance makes people retire much more quickly, about 50\% more for men and 78\% for women (Figure 3 and Figure 7). This is in direct contrast to being covered by your own insurance, in which husbands retire 31\% later than those not covered by their own insurance (17\% later for wives). On the graphs, the upper hazard curves represent persons being covered by their spouse's policy and the lower curve is those not covered by their spouse's policy. 
Examining one's own health shocks, Figure 4 shows the hazard curve for a different number of ADLs (and improvement, starting with -2) among husbands. Figure 8 shows the curves assuming a wife is injured versus not injured. As discussed above, being injured makes a wife more likely to retire.

For spousal health shocks, Figure 5 shows the case in which a husband's wife has an acute health shock, and Figure 9 shows the case in which a wife's husband has a short hospital stay. The lines in these graphs are not hugely different, reflecting the modest effect of spousal health shocks on changing the timing of retirement.

\section{Added Worker Effect.}

We examine whether the added worker effect is an important consideration (Coile, 2004b), meaning that people work more in the face of a spousal health shock to compensate earnings (Table 7).

Husbands.

We define a change in hours as current hours of work per week minus hours of work per week in the previous wave. We find that the financial incentives are not as strong predicting changes in hours worked, which makes sense intuitively. Workers often forgo tapping into retirement wealth by remaining in the labor force, so retirement assets are not as important in determining the hours worked. For example, an increase in $\$ 10,000$ in the PV measure would lead to only a two-minute per week increase, or a cumulative two hours of additional work over the course of a year (but this is only significant at the $10 \%$ level). Defined benefit wealth does not affect hours worked, and while Social Security PDV does have a statistically significant 
effect, it has a quantitatively small one; a $\$ 10,000$ increase in Social Security PDV would lead to only a 30-second reduction in hours worked per week.

Spousal health shocks become relatively more important when looking at changes in hours worked for men than in the discrete retirement decision. First, one’s own health shocks such as a long hospitalization, lead to a reduction in hours worked per week of about 1 hour. A new injury (a fall that required medical attention, a hip fracture, or an accident that led one to report a health problem) reduced the hours of work per week by 3.4 hours on average.

If one's wife experiences a new IADL limitation due to a health problem (recall that IADLs often measure executive functioning and cognitive ability), the husband reduces his hours worked per week by just over half an hour. If his wife experiences new pain, he reduces his hours by 48 minutes a week on average. Interestingly, if we include individual indicator variables for health instead of the composite measures some health conditions lead to increases in hours worked, while others lead to decreases. For example, if one's wife has new incontinence issues, the husband increases hours by about 1 hour per week whereas the wife having one additional IADL reduces hours by half an hour a week of work on average (results available upon request).

Wives.

Financial incentives. Of the woman's own financial incentives, neither PV nor PDV affect the number of hours of work per week. Defined contribution wealth is significant, however, with an additional $\$ 10,000$ in DC wealth leading to a reduction in work by about half an hour a week. Increasing a woman's annual earnings by $\$ 10,000$ reduces work by about two hours a week on average. A wife with low levels of liquid assets (in the lowest quartile) increases her work by just less than one hour per week compared with the highest asset quartile. 
Health shocks. Experiencing an acute health shock is associated with a decrease of 2.25 hours of work a week. New mental health problems (depression or psychiatric problem) decreased hours slightly less, with wives working 1.73 fewer hours. Similar to the probability of completely retiring, the husband's health shocks still do not influence a woman's hours worked, regardless of the definition of health shocks (Table 7, column 2). This latter finding suggests that there is not a strong added worker effect to insure against a husband's illness.

Robustness checks.

Heterogeneity.

We expect the effect on retirement to be heterogeneous among different individuals. As a test of this, we examine whether the work environment and attitude toward work have a differential effect on how people respond to financial incentives and health shocks. However, liking one's job is actually positively associated with the probability of retiring in the next period. The effect is statistically significant, but quantitatively small in magnitude for men, just under $1 \%(0.87 \%)$. Women were about $2 \%$ more likely to retire if they liked their job. This finding is somewhat counterintuitive. We hypothesize that this might be picking up an “anticipation effect.” Perhaps when one is reaching the end of their working life, they actually begin to like their job more, in anticipation of leaving. Further work into this would be valuable. Complementarity of leisure.

Another reason individuals may be retiring together is simply that they enjoy shared leisure time. Maestas (2001) and Coile (2004b) explore this possibility in their work on retirement incentives among couples and the retirement decision. We explore this using a 
seemingly unrelated regression model, allowing for the error terms to be correlated across

husbands and wives and modeling the decision as a joint decision. We eliminated two waves of data (1996 and 1998) in which this question was missing or asked only at the household level. In addition, this analysis required matching husbands to wives, and that both members of the couple be working initially, which was not a requirement in the earlier specifications. The SUR model controls for the variables in the main models, as well as an indicator variable measuring whether it is enjoyable to spend time with one's spouse. We code an agreement of either of these two questions as 1: "I like to spend time doing things together with my spouse," and "Time spent with my spouse is extremely enjoyable," in order to examine whether there were complementarities of leisure that explained the retirement decision. If a wife enjoys spending leisure time with her husband, she is $2.8 \%$ more likely to retire. We find no similar effect for husbands.

Health insurance and long-term care insurance.

The sources of health insurance may influence whether a person would need to retire in the presence of a spousal health shock. If a worker is the only source of health insurance coverage, he or she may be more likely to keep working if a spouse experiences a negative change in health. Hence, we examine whether having a spouse who was not offered insurance on the job affects the decision to retire, interacting it with spousal health shocks. We define health shocks in this check as a spouse having any new health shock from those listed in Table 2. We find that if one's wife does not have an offer of insurance and she has a health shock, the husband will be significantly less likely to retire. This group of variables are jointly significant at the 5\% level ( $X_{3}^{2}=9.2^{* *}$ ); however, on close inspection, the joint significance comes from a spouse not having an offer of insurance; the significance of the interaction term is not significant. 
We conclude from this that the lack of an offer of insurance for a wife affects the retirement decision of the husband but there is no differential effect of a spouse's health shock and not having insurance on the job and the husband's retirement decision. These interactions were not significant for women, again because a health shock to one’s husband does not affect the retirement decision.

Long-term care insurance may also impact the retirement response to a spousal health shock, but for different reasons. If the spouse is covered by long-term care insurance, the individual may not need to become a caregiver in the event of a health shock, and is freer to stay in the labor market. However, their income is also less important since the formal care costs are covered, so they may feel less financial pressure to stay in the labor force. It is difficult to say, prima facie, which effect would dominate. We interact "spouse has long-term care" with “spouse had a new IADL” as well as with "spouse had new pain.” We find that these interaction terms as a group do not significantly increase the risk of retirement. However, they are jointly significant $\left(\mathrm{F}(5,8351)=2.57^{* *}\right)$ in increasing the hours a husband works per week on average. ${ }^{6}$ In particular, there is a differential increase in hours worked per week for men whose spouses have long-term care insurance coverage and have had an increase in IADLS (combined effect across linear and interaction terms is an increase of just over two hours a week on average (0.113-1.607+2.89). Therefore, we take this as evidence that a wife having long-term care insurance frees the husband to remaining working.

Retirement expectations.

We also examine whether information about a person's expected retirement age is significant in predicting retirement behavior, even after accounting for all of the financial

\footnotetext{
${ }^{6}$ We test this only for male workers because none of the husband's health shocks matter in the wife's retirement decision (or in the number of hours a woman works).
} 
incentives and health shocks. The HRS includes the question, "Thinking about work in general and not just your present job, what do you think the chances are that you will be working fulltime after you reach age 65?” Knowing whether expectations are influential is useful in considering different policy changes to Social Security. For example, one proposed change in the Social Security program is changing the definition of full retirement age to age 70, without changing the actual benefit formulas. The delayed retirement credits that apply between the current full retirement age and age 70 would simply be re-labeled as part of the actuarial adjustment for claiming benefits early. This change of the frame in the benefits could also change people's perceptions of when they will retire. What we test here is whether that change in perception, keeping all the financial benefits to retirement unchanged, would impact retirement behavior. We find that husbands who think they will work after age 65 are actually much less likely to retire, even after controlling for forward-looking financial incentives and health shocks. This sample is younger than our main models, since one had to be under 65 to be asked the question; therefore, the baseline predicted risk of retirement is 9 percent for both the husbands and wives. If everyone expected to work past age 65, this model suggests a substantial decline in that risk to only $5.5 \%$ and $4.4 \%$ for husbands and wives, respectively. The marginal effects of the financial incentive variables and health shock variables did not change noticeably with the addition of this variable (results available upon request). Nevertheless, this extension suggests the important role that expectations play, and changing expectations could dramatically change the labor force participation decisions of older workers.

Finally, we examine whether there are differential effects by age on the retirement decision, by fully interacting age categories ${ }^{7}$ with one’s own acute and chronic health shocks. We find that there is a differential effect of being at a higher age and having a health shock on

\footnotetext{
${ }^{7}$ We defined the age categories to be age 52-54 (reference), 55-60, 61-65, and 66-69.
} 
the retirement decision. Compared with people aged 52-54, men who were older and had a health shock were actually less likely to retire. This could be either to unobserved heterogeneity of the severity of the health shock or, more likely, older individuals still in the work force are more attached to the labor force than their younger counterparts, and are therefore less responsive to changes in health. There is no differential effect for wives.

\section{Counterfactuals.}

Using our results, we examine retirement patterns under different Social Security scenarios, and changes in health shocks from changes in medical technology, a medical advance, or the predicted worsening of health due to the rise in obesity. Table 8 highlights the counterfactuals, as well as the baseline (unadjusted) risk of retirement and the adjusted risk from our preferred models. We describe the predicted probability under the different scenarios as well as the absolute difference in predicted probability and the relative difference in the predicted probability from a given scenario.

Reducing Social Security benefits.

One scenario that would bring the Social Security program back to long-term solvency is an across-the-board reduction in benefits by 13.3\% (Munnell, Sass, and Eschtruth, 2009). Using the results from our models, reducing Social Security wealth by $13.3 \%$ (which impacts PV and PDV) would lead to no change in the retirement decision. While the coefficients of the estimated model are significant, the change in the benefits is just too small to dramatically change retirement behavior. ${ }^{8}$

\footnotetext{
${ }^{8}$ One caveat that should be highlighted, however, is that we are making out-of-sample predictions, and only doing partial equilibrium analysis here.
} 
Improvements in health.

As a baseline simulation, we replace all individual health shock values with zeros to measure the direct effect of health shocks on retirement. Similarly, we replace the health shock value of the spouse at zero to see the direct effect of an individual health shock on retirement. In the retirement decision of the husband (Table 7, column 1), having no new health shocks himself leads to a small reduction in the chance of retirement, of .116. This represents a $6.5 \%$ lower predicted probability compared to the baseline prediction (0.124). Eliminating health shocks to the wife leads to a very small reduction in the risk (absolute difference of -.004). Eliminating health shocks for both members of the couple reduces the relative risk of retirement by $9.7 \%$. By comparison, examining a wife's retirement decision (column 2, Table 8), eliminating health shocks for both members of the couple reduces the risk of retirement by $2.9 \%$.

Thinking of future medical advances, we want to examine how improvements in pharmaceutical or other treatment advances for high blood pressure (and resultant stroke or heart attack avoided) or for depression or emotional problems would affect the retirement decision. The effects are quite modest, which is not surprising, given that these individual health shocks were small in magnitude and imprecisely estimated (with the exception of heart attack for men). Eliminating high blood pressure and resultant diseases does not have a noticeable effect on retirement for husbands or wives. Eliminating mental health problems reduces the relative risk of retirement for husbands by about $3.2 \%$ ( $1 \%$ for women).

Declines in health.

Using models that include the individual health shock indicators, we can see the important shocks correlated with the risk of retirement. For the husband's retirement decision, experiencing diabetes, a heart attack, and two ADL limitations lead to a 46\% relative increase in 
the risk of retirement compared with the baseline. If both members of the couple experience health shocks (where the wife has a long hospital stay and the husband gets the conditions described above), there would be a $68.5 \%$ relative increase in the risk of retirement. For women, however, the effect is quite different. A wife who experiences bad health shocks (new cancer, new arthritis, and new pain) would be $10 \%$ less likely to retire compared with the baseline predicted probability. ${ }^{9}$

\section{Effects of obesity.}

Because there is evidence that obesity increases workers compensation claims and workdays lost (Ostbye, Dement, and Krause, 2007), and because prevalence of obesity is rising nationwide, we examine the impact of obesity on the likelihood of retiring. We do not include Body Mass Index over 25 in the model—the standard definition of obesity—because selfreported BMI measures tend to be of very low quality (Cawley and Burkhauser, 2006). Obesityrelated conditions include diabetes, high blood pressure, two limitations in ADLs, angina, incontinence, heart condition, and pain. ${ }^{10}$ To be sure, our list of obesity-related conditions is long, and individuals would be unlikely to experience all of these in one two-year period. Nevertheless, this counterfactual provides an upper-bound estimate of the effects of obesity. We compare the predicted probability of retirement among individuals with baseline characteristics to individuals with obesity-related conditions. Husbands with onset of the obesity-related conditions has a risk of retirement of 0.261 , representing a $110 \%$ increase in the risk compared with the baseline predicted risk of retirement. A wife having obesity-related conditions did not affect a husband's chance of retirement. For wives, having obesity-related

\footnotetext{
${ }^{9}$ We did not change the husband's health because a husband's health shocks did not influence a woman's retirement decision.

${ }^{10}$ We are indebted to Will Yancy, MD, for his input on obesity-related conditions.
} 
conditions themselves leads to a $28.2 \%$ reduction in the risk of retiring. If only the husband attains these conditions, the wife would have a 38.8\% increase in her risk of retirement. If they both had the market-basket of obesity-related conditions, the effect cancels out, leaving wives no more or no less likely to retire. This last counterfactual suggests that a model of retirement that only considered obesity-related shocks for the individual and not for the spouse would lead to incorrect conclusions about the effects on retirement.

Overall, it appears that changes to the Social Security benefit will have modest effects on retirement, whereas the effects of individual health shocks for men (and to a lesser extent for wives) and obesity-related conditions for men would have a steep increase in the risk of retirement.

\section{Conclusion}

We find that in a discrete-time retirement model for married individuals, where one controls for both financial incentives and individual and spousal health shocks, financial incentives win out. We find that financial incentives are the most important determinant of retirement behavior empirically. A husband is about half as responsive to his wife's financial incentives as he is to his own. In addition, one's own health shocks are relatively more important than health shocks experienced by one's spouse. This was not the case with financial incentives. One's own financial incentives and the financial incentives of one's spouse remain important when controlling for health shocks to oneself or one's spouse. Interestingly, the effect of spousal health shocks is somewhat different based on whether the model was estimated with a probit or hazard function. We find that married men are responsive to their wives' health shocks, on both the intensive and extensive margin, but that they do not retire more quickly based on a 
spousal health shock. We find a wife's decision concerning work is largely unaffected by her husband's health shocks, on both the intensive and extensive margin, but that women will retire more quickly if their husband has a new chronic condition and retire less quickly if he has a short hospital stay. These conflicting effects from the hazard model may explain why we find null effects in the discrete model of a wife's retirement decision.

Our results are also robust to many other factors that may explain the retirement decision: the definition of health shocks, the existence of complementarity of leisure, expectations about retirement, and sources of health and long-term care insurance covering one's spouse. One limitation of our study is that the devised counterfactuals are somewhat extreme, and are only done in partial equilibrium. That is, rarely would one experience sudden onset of obesity, so the measured increase in retirement risk from “new obesity-related conditions” is likely exaggerated. In addition, we were unable to devise a counterfactual that illustrated the importance of SS benefit rules changes in the retirement decision. It appears from the one counterfactual we rana 13.3\% reduction in benefits-that there would be very small changes in retirement behavior. In revisions we will look for other ways to illustrate how changes in SS benefits might work through PDV and PV to affect retirement.

Future work should examine the extreme case of the death of a spouse in order to better understand how the death of one's spouse influences one's own retirement decision. This would allow us to explore further any financial considerations for retirement that are not associated with spousal complementarities of leisure. 
Figure 1. Raw Retirement Hazards by Gender

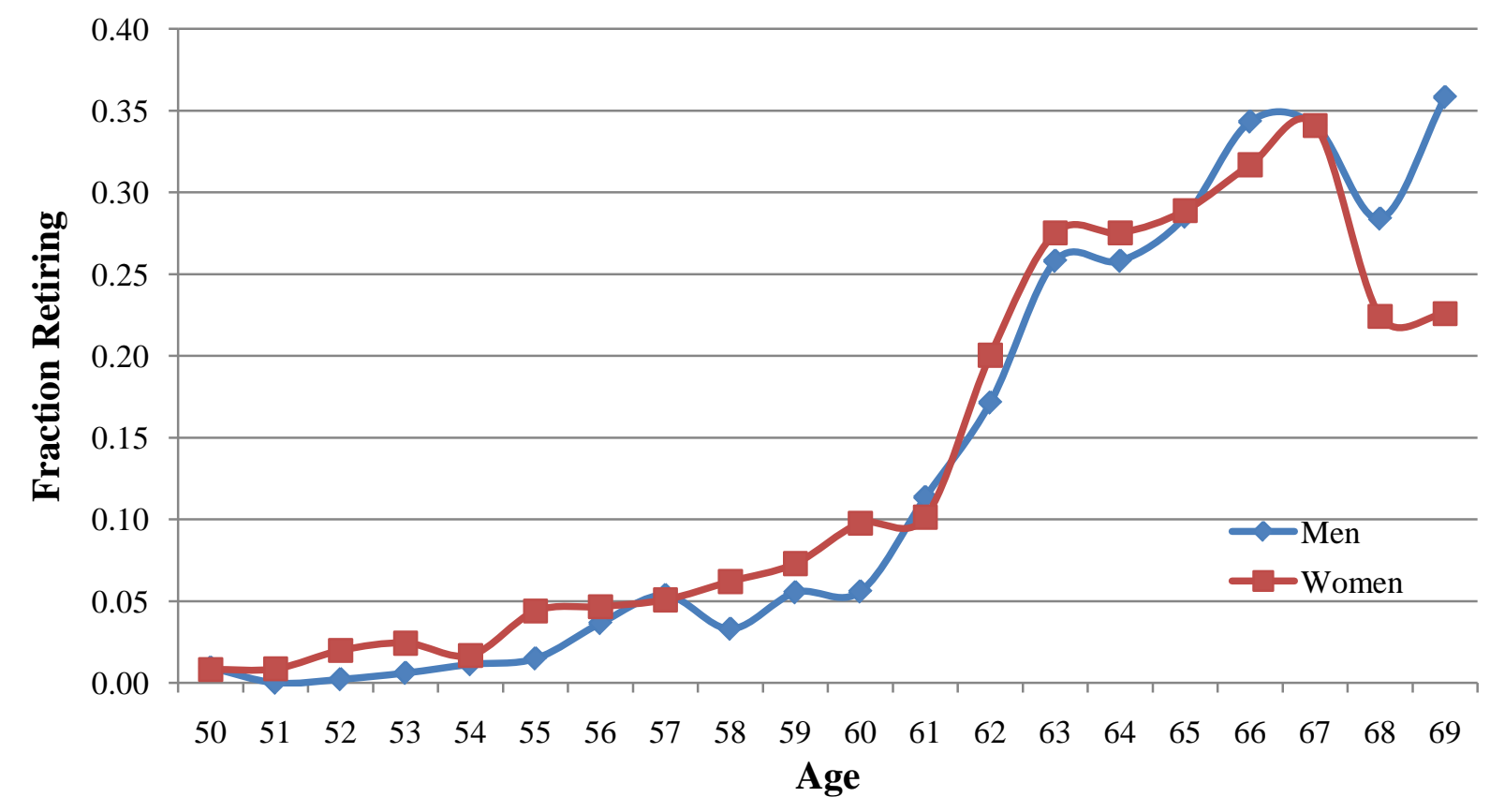

Source: The authors' tabulations of the Health and Retirement Study. 
FIGURE 2: Husband's hazard model results given different earnings profiles

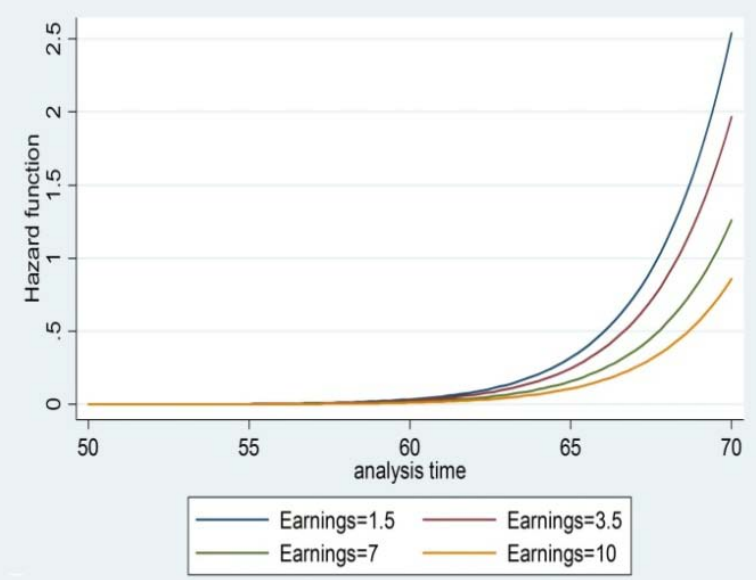

FIGURE 4: Husband's hazard model results given ADL shocks

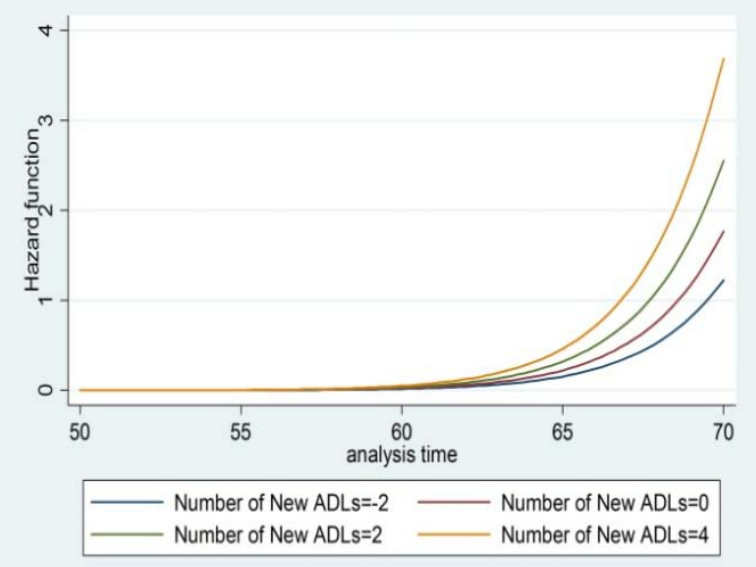

FIGURE 3: Husband's hazard model results given health insurance comes from spouse

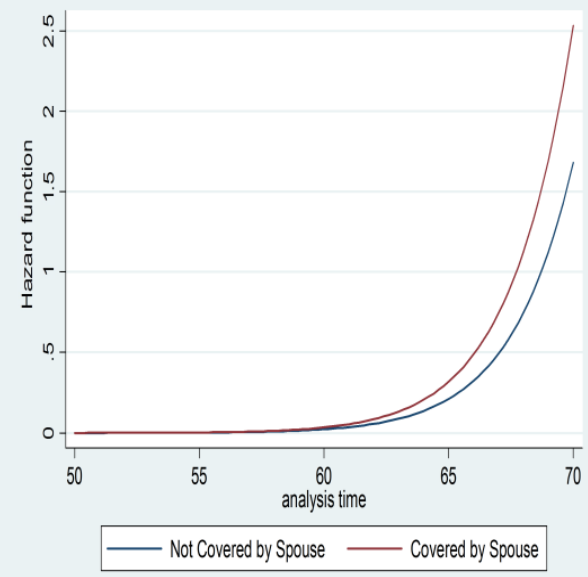

FIGURE 5: Husband's hazard model results given wife's acute shocks

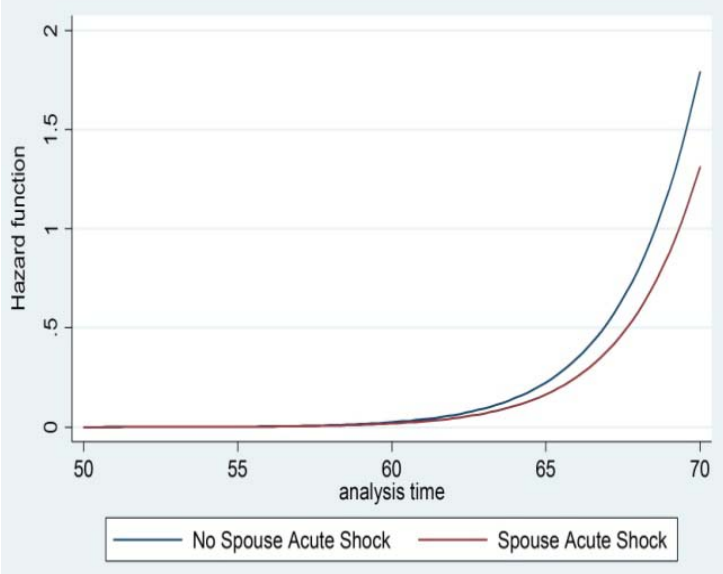


FIGURE 6: Wife's hazard model results given different earnings profiles

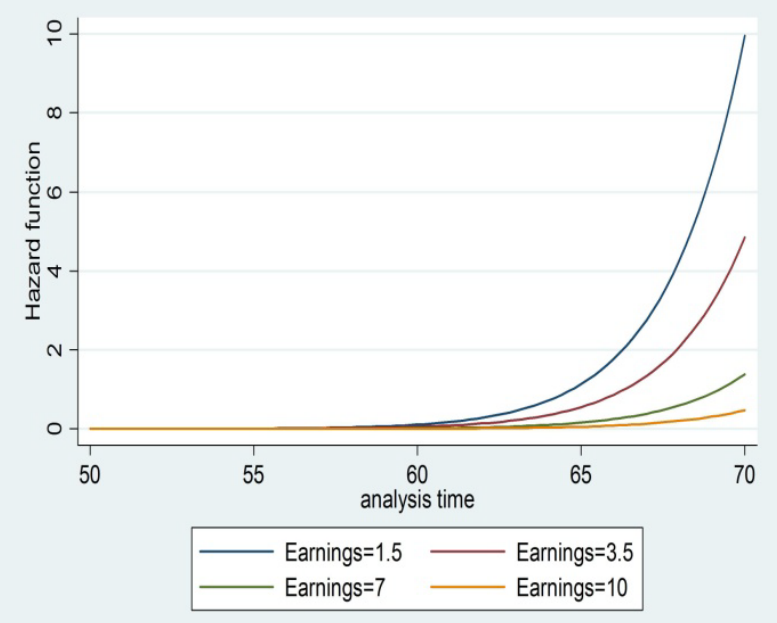

FIGURE 8: Wife's hazard model results given new injuries

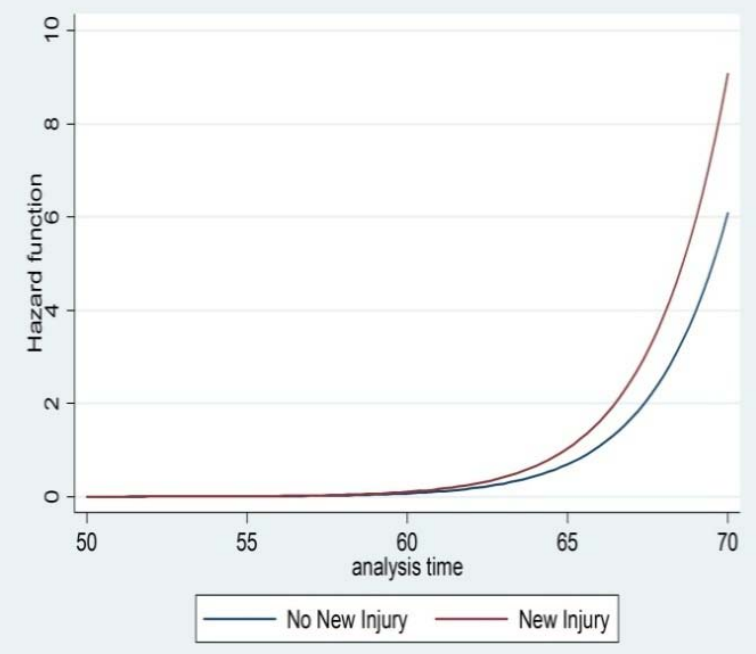

FIGURE 7: Wife's hazard model results given health insurance comes from spouse

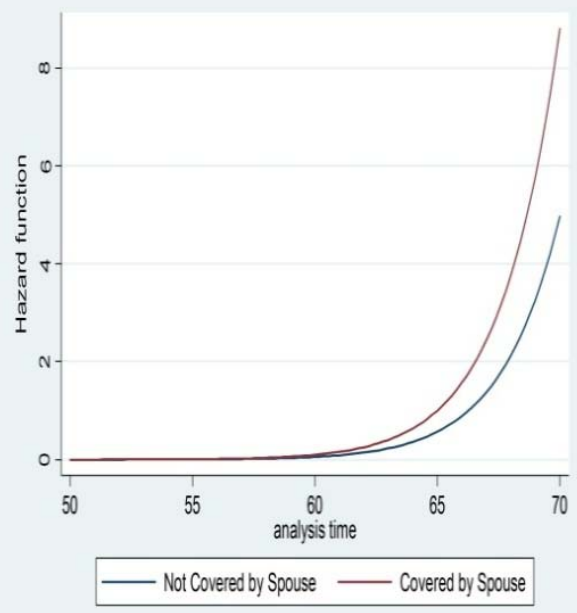

FIGURE 9: Wife's hazard model results given husband's short hospital stay

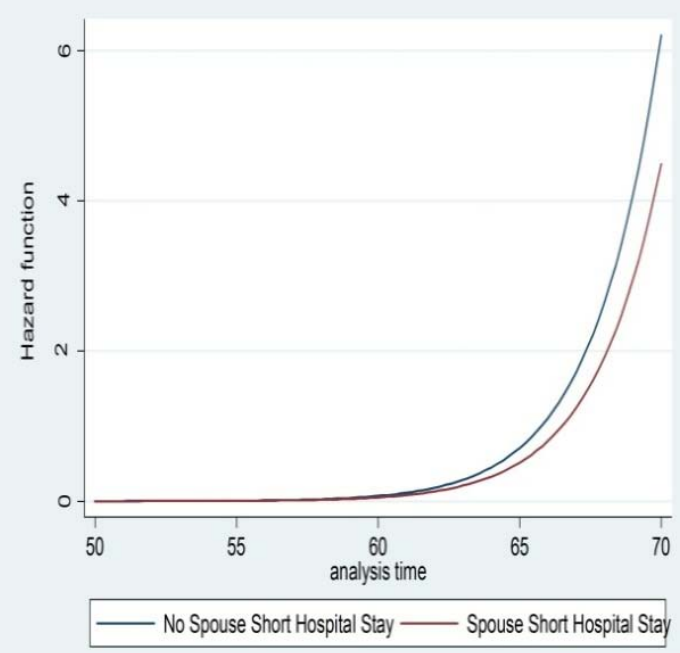


Table 1. Sample attrition by men and women person-waves

MEN

WOMEN

Initial sample of person-waves (1992-2006):

56,339

76,037

Married first year they enter survey

44,644

47,995

Working first year they enter survey

30,049 25,816

Valid earnings value (either SSA or RAND earnings)

26,147

23,346

Age between 50 and 69

22,559 19,209

Spouse between age 40 and 69

21,113 15,481

Change spouses during time period

20,931

15,359

Never applied for disability insurance

18,739

14,006

Not self-employed

15,607

12,874

Observations while working or the wave in which

12,919

10,586

they report retiring

Eliminate the first obs per person for a baseline

8,447

6,854

Number of individuals

$3,357 \quad 3,448$


Table 2. Descriptive statistics of individual men and women in the sample

\section{(proportion unless noted)}

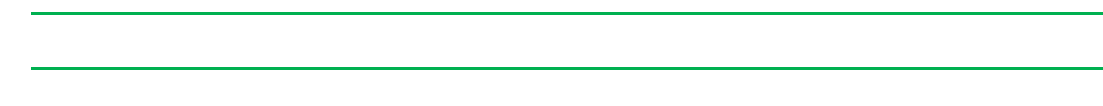
Men Women

Retired

Change in weekly hours worked between waves among those not retiring $\left(\mathrm{w}_{\mathrm{t}}-\mathrm{w}_{\mathrm{t}-1}\right)$

0.358

$-1.9$

0.288

$-1.9$

Retirement Wealth

Present discounted value of Social Security wealth (c=couple)

Peak Value of Social Security Wealth (c)

Present Discounted Value of Defined Benefit Wealth (i)

Defined Contribution Wealth (i)

Annual Earnings (i)

Net worth ${ }^{2}$ (c)

Liquid assets $^{2}$ (c)

Health Shocks

Acute Health Shocks (ever had new shock b.t. 1994-2006)

New heart attack or infarction ${ }^{3}$

New stroke ${ }^{4}$

New cancer $^{4}$

New Chronic Condition (ever had new shock b.t. 1994-2006)

New Arthritis ${ }^{4}$

New High Blood Pressure ${ }^{3}$

New Heart Condition ${ }^{4}$

New Diabetes ${ }^{4}$

New Incontinence ${ }^{3}$

New Lung Disease ${ }^{4}$

New Angina ${ }^{3}$

New Heart Failure ${ }^{3}$

New Mental Health Problem

New depression (CESD8>4) ${ }^{3}$

New psychological diagnosis ${ }^{4}$

New Injury ${ }^{5}$

Number of New ADL Limitations ${ }^{4}$

Number of New IADL Limitations ${ }^{4}$

Any Recent Hospitalization ${ }^{3}$

Had a One Night Stay

Had More Than a One Night Stay

Demographics

White

Black
$335,153.9$

$78,750.8$

$70,812.9$

$32,209.1$

$46,061.0$

238,146.2

16,051.6

0.153

0.077

0.015

0.065

0.573

0.347

0.222

0.115

0.115

0.069

0.058

0.051

0.019

0.145

0.102

0.057

0.049

0.136

0.137

0.368

0.124

0.290

0.860

0.107
$334,688.9$

$64,416.8$

$53,636.8$

$15,602.8$

29,335.5

269,084.4

0.094

0.020

0.005

0.069

0.609

0.382

0.212

0.066

0.080

0.205

0.056

0.031

0.009

0.231

0.166

0.104

0.043

0.127

0.205

0.315

0.110

0.235

0.849

0.124
$18,802.1$ 
Other race

0.033

0.027

Hispanic

0.059

0.037

Born in US

0.901

0.920

Potential Work Experience (age - (years of education+6))

48.6

Tenure on Job

Union

0.318

0.247

Missing Union

0.001

0.000

Health Insurance

Through Individual's Job

0.802

0.570

Through Spouse's Job

0.149

0.435

Medicare $^{6}$

0.018

0.005

Medicaid $^{6}$

0.002

0.002

Veterans Affairs ${ }^{6}$

0.044

0.031

None (reference category)

0.058

0.062

Retiree Health Insurance

Retiree Health Insurance Available

0.488

0.288

Missing Value on Retiree Health Insurance

0.295

0.511

Individuals

3,098

1 Divided the financial variables by 10,000 in the models, and earnings squared by $(1,000,000)$, cubed by $(1,000,000,000)$ and earnings quadratic term by $(1,000,000,000,000)$.

${ }^{2}$ In the models are included as quartiles with the highest quartile being the reference category.

${ }^{3}$ Asked as ever had so we coded it as one if they did not have it in the last period but had it in the current period.

${ }^{4}$ Question worded as whether a person "currently has" the condition or "in the past two years/since the last interview" so coded as one if they did not have it last period but currently have it.

${ }^{5}$ Coded as 1 if they had a recent fall that required medical attention; a hip fracture; or an accident that caused a current health problem.

${ }^{6}$ These are combined into the reference category of "public insurance." 
Table 3. Probit model of men's probability of self-reported retirement

$\begin{array}{llll}\text { Own } & + \text { Own } & \text { + Spouse's } & \text { + Spouse's } \\ \text { Financial } & \text { Health } & \text { Financial } & \text { Health } \\ \text { MODEL 1 } & \text { MODEL 2 } & \text { MODEL 3 } & \text { MODEL 4 } \\ \text { dy/dx } & \text { dy/dx } & \text { dy/dx } & \text { dy/dx } \\ \text { (s.e.) } & \text { (s.e.) } & \text { (s.e.) } & \text { (s.e.) }\end{array}$

\begin{tabular}{|c|c|c|c|c|}
\hline $\begin{array}{l}\text { Own/Couple's Financial } \\
\text { Incentives }\end{array}$ & & & & \\
\hline Peak Value of SS Wealth (PV) & $\begin{array}{l}-0.0088 * * * \\
(7.20)\end{array}$ & $\begin{array}{l}-0.0086 * * * \\
(7.15)\end{array}$ & $\begin{array}{l}-0.0085^{* * *} \\
(7.09)\end{array}$ & $\begin{array}{l}-0.0084^{* * *} \\
(7.13)\end{array}$ \\
\hline Expected present discounted & $0.0002 * * *$ & $0.0002 * * *$ & $0.0002 * * *$ & $0.0002 * * *$ \\
\hline & $(2.70)$ & $(2.68)$ & $(2.62)$ & $(2.60)$ \\
\hline $\begin{array}{l}\text { Expected present discounted } \\
\text { value of DB wealth (PDV) }\end{array}$ & $0.0002 * * *$ & $0.0002 * * *$ & $0.0002 * * *$ & $0.0002 * * *$ \\
\hline & $(4.83)$ & $(4.83)$ & $(4.79)$ & $(4.80)$ \\
\hline Defined contribution wealth & $\begin{array}{l}0.0001^{*} \\
(1.72)\end{array}$ & $\begin{array}{l}0.0001 * \\
(1.68)\end{array}$ & $\begin{array}{l}0.0001 \\
(1.61)\end{array}$ & $\begin{array}{l}0.0001 \\
(1.59)\end{array}$ \\
\hline Annual earnings & $\begin{array}{l}-0.0464 * * * \\
(15.61)\end{array}$ & $\begin{array}{l}-0.0456^{* * *} \\
(15.49)\end{array}$ & $\begin{array}{l}-0.0449 * * * \\
(15.27)\end{array}$ & $\begin{array}{l}-0.0449 * * * \\
(15.29)\end{array}$ \\
\hline Net worth quartile 1 & $\begin{array}{l}-0.0301 * * * \\
(5.88)\end{array}$ & $\begin{array}{l}-0.0298 * * * \\
(5.87)\end{array}$ & $\begin{array}{l}-0.0294 * * * \\
(5.79)\end{array}$ & $\begin{array}{l}-0.0294 * * * \\
(5.81)\end{array}$ \\
\hline Net worth quartile 2 & $\begin{array}{l}-0.0259 * * * \\
(5.76)\end{array}$ & $\begin{array}{l}-0.0255^{* * *} \\
(5.79)\end{array}$ & $\begin{array}{l}-0.0245^{* * *} \\
(5.48)\end{array}$ & $\begin{array}{l}-0.0243^{* * *} \\
(5.49)\end{array}$ \\
\hline Net worth quartile 3 & $\begin{array}{l}-0.0077 * \\
(1.71)\end{array}$ & $\begin{array}{l}-0.0076 * \\
(1.71)\end{array}$ & $\begin{array}{l}-0.0064 \\
(1.43)\end{array}$ & $\begin{array}{l}-0.0065 \\
(1.46)\end{array}$ \\
\hline Liquid assets quartile 1 & $\begin{array}{l}-0.0144 * * * \\
(2.94)\end{array}$ & $\begin{array}{l}-0.0146 * * * \\
(3.04)\end{array}$ & $\begin{array}{l}-0.0144 * * * \\
(2.99)\end{array}$ & $\begin{array}{l}-0.0143^{* * *} \\
(2.99)\end{array}$ \\
\hline Liquid assets quartile 2 & $\begin{array}{l}-0.0080 * \\
(1.73)\end{array}$ & $\begin{array}{l}-0.0082 * \\
(1.80)\end{array}$ & $\begin{array}{l}-0.0077 * \\
(1.69)\end{array}$ & $\begin{array}{l}-0.0075^{*} \\
(1.67)\end{array}$ \\
\hline Liquid assets quartile 3 & $\begin{array}{l}-0.0129 * * * \\
(3.03)\end{array}$ & $\begin{array}{l}-0.0128 * * * \\
(3.05)\end{array}$ & $\begin{array}{l}-0.0123 * * * \\
(2.93)\end{array}$ & $\begin{array}{l}-0.0121^{* * * *} \\
(2.90)\end{array}$ \\
\hline Own Health Shocks & & & & \\
\hline Acute health shock & & $\begin{array}{l}0.0227 * * \\
(2.52)\end{array}$ & $\begin{array}{l}0.0217 * * \\
(2.44)\end{array}$ & $\begin{array}{l}0.0221 * * \\
(2.47)\end{array}$ \\
\hline New chronic condition & & $\begin{array}{l}0.0083^{* *} \\
(2.09)\end{array}$ & $\begin{array}{l}0.0080^{* *} \\
(2.02)\end{array}$ & $\begin{array}{l}0.0078 * * \\
(1.99)\end{array}$ \\
\hline New mental health problem & & $\begin{array}{l}-0.0039 \\
(0.59)\end{array}$ & $\begin{array}{l}-0.0036 \\
(0.55)\end{array}$ & $\begin{array}{l}-0.0036 \\
(0.55)\end{array}$ \\
\hline Number of new IADLs & & $\begin{array}{l}-0.0007 \\
(0.17)\end{array}$ & $\begin{array}{l}-0.0006 \\
(0.15)\end{array}$ & $\begin{array}{l}-0.0009 \\
(0.21)\end{array}$ \\
\hline Number of new ADLs & & $\begin{array}{l}0.0131 * * * \\
(3.42)\end{array}$ & $\begin{array}{l}0.0134 * * * \\
(3.49)\end{array}$ & $\begin{array}{l}0.0132 * * * \\
(3.45)\end{array}$ \\
\hline New Injury & & 0.0181 & 0.0162 & 0.0150 \\
\hline
\end{tabular}


New Pain

Short hospitalization

Long hospitalization

\section{Spouse's Financial}

\section{Incentives}

Expected present discounted value of DB wealth (PDV)

Defined Contribution wealth

Annual earnings

\section{Spouse's Health Shocks}

Acute health shock

New chronic condition

New mental health problem

Number of new IADLs

Number of new ADLs

New Injury

New Pain

Short hospitalization

Long hospitalization

Own Baseline Health

Health Insurance

Through Individual's Job

Through Spouse’s Job

Public Insurance

Retiree Health Insurance Available

$\begin{array}{lll}(1.45) & (1.32) & (1.24) \\ -0.0005 & -0.0006 & -0.0005 \\ (0.10) & (0.11) & (0.10) \\ 0.0097 & 0.0108 & 0.0116 \\ (1.21) & (1.33) & (1.42) \\ 0.0008 & 0.0014 & 0.0010 \\ (0.15) & (0.27) & (0.20)\end{array}$

$\begin{array}{ll}0.0001^{* *} & 0.0001^{* *} \\ (2.30) & (2.32) \\ 0.0001 & 0.0001 \\ (1.45) & (1.42) \\ -0.0121^{* * *} & -0.0118^{* * *} \\ (3.90) & (3.82)\end{array}$

$-0.0120$

(1.63)

$-0.0008$

$(0.23)$

$-0.0030$

(0.61)

0.0020

(0.60)

$-0.0019$

(0.75)

$-0.0031$

(0.59)

0.0024

(0.26)

$-0.0092$

(1.36)

$0.0145^{* * *}$

(2.65)

$0.0062 * *$

$0.0062 * *$

(2.16)

\section{(2.88)}

(2.12)

(2.14)

$-0.0009$

$\begin{array}{ll}-0.0013 & -0.0015 \\ (0.19) & (0.23) \\ 0.0219 * * * & 0.0207 * * * \\ (3.29) & (3.15) \\ 0.0447 * * * & 0.0437 * * * \\ (4.66) & (4.59) \\ 0.0121 * * * & 0.0121 * * *\end{array}$

$-0.0009$

(0.14)

$0.0242 * * *$

$0.0237 * * *$

(3.46) (3.43)

$0.0419 * * *$

(4.46)

$0.0414 * * *$ (4.44)

$0.0121 * * *$ 


\begin{tabular}{lllll} 
& $(2.78)$ & $(2.84)$ & $(2.83)$ & $(2.90)$ \\
Missing Retiree Insurance & $-0.0410^{* * *}$ & $-0.0405^{* * *}$ & $-0.0402 * * *$ & $-0.0397^{* * *}$ \\
& $(6.53)$ & $(6.52)$ & $(6.52)$ & $(6.49)$ \\
Job Characteristics & & & & \\
Potential Experience & -0.0017 & -0.0018 & -0.0016 & -0.0017 \\
& $(1.21)$ & $(1.23)$ & $(1.12)$ & $(1.21)$ \\
Tenure on job & $0.0014 * * *$ & $0.0014 * * *$ & $0.0014 * * *$ & $0.0014 * * *$ \\
& $(10.37)$ & $(10.40)$ & $(10.32)$ & $(10.32)$ \\
Member of a union & $0.0120^{* * *}$ & $0.0116 * * *$ & $0.0107 * * *$ & $0.0107^{* * *}$ \\
& $(3.24)$ & $(3.20)$ & $(2.95)$ & $(2.98)$ \\
Pseudo R-squared & & & & \\
Observations & 0.343 & 0.349 & 0.352 & 0.354 \\
\hline
\end{tabular}

$*$ indicates significance at the $10 \%$ level; **indicates significance at the $5 \%$ level; *** at $1 \%$ level. Standard errors are robust.

Note: Recall that PDV, PV, DC wealth and earnings are expressed in \$10,000s of dollars. Thus dy/dx is represents a 100 x percentage point change in the probability of retiring for a $\$ 10000$ dollar change in these $\mathrm{x}$ variables. Model also controls for squared, cubed, and quadratic earnings terms, full set of age dummies (52-60), age difference between spouse and self, education (some college, college, and missing), Hispanic, Other race, Black, and missing race, born in US, missing value on born in US, experience squared, missing value on union status, and wave dummies. 
Table 4. Probit model of women's probability of self-reported retirement

\begin{tabular}{|c|c|c|c|c|}
\hline & $\begin{array}{l}\text { Own } \\
\text { Financial }\end{array}$ & $\begin{array}{l}+ \text { Own } \\
\text { Health }\end{array}$ & $\begin{array}{l}\text { + Spouse's } \\
\text { Financial }\end{array}$ & $\begin{array}{l}\text { + Spouse's } \\
\text { Health }\end{array}$ \\
\hline & $\begin{array}{l}\text { MODEL } 1 \\
\text { dy/dx } \\
\text { (s.e.) }\end{array}$ & $\begin{array}{l}\text { MODEL } 2 \\
\text { dy/dx } \\
\text { (s.e.) }\end{array}$ & $\begin{array}{l}\text { MODEL } 3 \\
\mathrm{dy} / \mathrm{dx} \\
\text { (s.e.) }\end{array}$ & $\begin{array}{l}\text { MODEL } 4 \\
\text { dy/dx } \\
\text { (s.e.) }\end{array}$ \\
\hline \multicolumn{5}{|l|}{$\begin{array}{l}\text { Own/couple's Financial } \\
\text { Incentives }\end{array}$} \\
\hline \multirow{2}{*}{$\begin{array}{l}\text { Peak Value of Social Security } \\
\text { Wealth (PV) }\end{array}$} & $-0.0052 * * *$ & $-0.0052 * * *$ & $-0.0049 * * *$ & $-0.0049 * * *$ \\
\hline & (5.68) & (5.67) & $(5.34)$ & $(5.36)$ \\
\hline \multirow{2}{*}{$\begin{array}{l}\text { Expected present discounted } \\
\text { value of SS wealth (PDV) }\end{array}$} & $0.0003 * * *$ & $0.0003 * * *$ & $0.0003 * * *$ & $0.0003^{* * *}$ \\
\hline & (3.28) & (3.28) & (3.10) & (3.07) \\
\hline \multirow{2}{*}{$\begin{array}{l}\text { Expected present discounted } \\
\text { value of DB wealth (PDV) }\end{array}$} & $0.0002 * * *$ & $0.0002 * * *$ & $0.0002 * * *$ & $0.0002 * * *$ \\
\hline & (3.66) & (3.64) & (3.54) & $(3.50)$ \\
\hline \multirow{2}{*}{ Defined contribution wealth } & $0.0001 *$ & $0.0001 *$ & 0.0001 & 0.0001 \\
\hline & $(1.66)$ & (1.69) & $(1.60)$ & (1.49) \\
\hline \multirow[t]{2}{*}{ Annual earnings } & $-0.0965 * * *$ & $-0.0959 * * *$ & $-0.0929 * * *$ & $-0.0923 * * *$ \\
\hline & (14.65) & $(14.63)$ & $(14.49)$ & (14.47) \\
\hline Net worth quartile 1 & $-0.0287 * * *$ & $-0.0285 * * *$ & $-0.0268 * * *$ & $-0.0272 * * *$ \\
\hline \multirow{2}{*}{ Net worth quartile 2} & $-0.0242 * * *$ & $-0.0245 * * *$ & $-0.0223 * * *$ & $-0.0227 * * *$ \\
\hline & $(3.87)$ & $(3.92)$ & $(3.55)$ & (3.63) \\
\hline \multirow[t]{2}{*}{ Net worth quartile 3} & -0.0084 & -0.0082 & -0.0067 & -0.0069 \\
\hline & $(1.39)$ & $(1.35)$ & $(1.11)$ & $(1.15)$ \\
\hline \multirow[t]{2}{*}{ Liquid assets quartile 1} & $-0.0234 * * *$ & $-0.0231 * * *$ & $-0.0223 * * *$ & $-0.0225 * * *$ \\
\hline & $(3.51)$ & $(3.47)$ & (3.37) & (3.43) \\
\hline \multirow[t]{2}{*}{ Liquid assets quartile 2} & $-0.0167 * * *$ & $-0.0165 * * *$ & $-0.0154^{* *}$ & $-0.0157 * * *$ \\
\hline & $(2.72)$ & $(2.70)$ & $(2.53)$ & (2.59) \\
\hline \multirow{2}{*}{ Liquid assets quartile 3} & -0.0044 & -0.0039 & -0.0027 & -0.0030 \\
\hline & $(0.73)$ & $(0.65)$ & $(0.46)$ & $(0.51)$ \\
\hline \multicolumn{5}{|l|}{ Own Health Shocks } \\
\hline \multirow[t]{2}{*}{ Acute health shock } & & 0.0234 & 0.0236 & 0.0230 \\
\hline & & $(1.55)$ & $(1.58)$ & $(1.55)$ \\
\hline \multirow[t]{2}{*}{ New chronic condition } & & 0.0016 & 0.0020 & 0.0021 \\
\hline & & $(0.31)$ & (0.39) & $(0.41)$ \\
\hline \multirow[t]{2}{*}{ New mental health problem } & & -0.0034 & -0.0035 & -0.0036 \\
\hline & & $(0.46)$ & $(0.48)$ & $(0.50)$ \\
\hline \multirow{2}{*}{ Number of new IADLs } & & -0.0003 & -0.0000 & 0.0007 \\
\hline & & $(0.05)$ & $(0.00)$ & $(0.12)$ \\
\hline \multirow[t]{2}{*}{ Number of new ADLs } & & 0.0009 & 0.0009 & 0.0008 \\
\hline & & $(0.16)$ & $(0.16)$ & $(0.15)$ \\
\hline
\end{tabular}




\begin{tabular}{|c|c|c|c|c|}
\hline New Injury & & $\begin{array}{l}0.0375^{* *} \\
(2.02)\end{array}$ & $\begin{array}{l}0.0356^{*} \\
(1.95)\end{array}$ & $\begin{array}{l}0.0374^{* *} \\
(2.04)\end{array}$ \\
\hline New Pain & & $\begin{array}{l}0.0017 \\
(0.21)\end{array}$ & $\begin{array}{l}0.0015 \\
(0.19)\end{array}$ & $\begin{array}{l}0.0015 \\
(0.20)\end{array}$ \\
\hline Short hospitalization & & $\begin{array}{l}-0.0062 \\
(0.60)\end{array}$ & $\begin{array}{l}-0.0066 \\
(0.65)\end{array}$ & $\begin{array}{l}-0.0056 \\
(0.55)\end{array}$ \\
\hline Long hospitalization & & $\begin{array}{l}-0.0034 \\
(0.44)\end{array}$ & $\begin{array}{l}-0.0026 \\
(0.34)\end{array}$ & $\begin{array}{l}-0.0020 \\
(0.26)\end{array}$ \\
\hline $\begin{array}{l}\text { Spouse's Financial } \\
\text { Incentives }\end{array}$ & & & & \\
\hline $\begin{array}{l}\text { Expected present discounted } \\
\text { value of DB wealth (PDV) }\end{array}$ & & & $\begin{array}{l}0.0002 * * * \\
(3.09)\end{array}$ & $\begin{array}{l}0.0002 * * * \\
(3.13)\end{array}$ \\
\hline Defined Contribution wealth & & & $\begin{array}{l}0.0002 \\
(1.57)\end{array}$ & $\begin{array}{l}0.0002 \\
(1.56)\end{array}$ \\
\hline Annual earnings & & & $\begin{array}{l}-0.0091^{* * *} \\
(2.87)\end{array}$ & $\begin{array}{l}-0.0085^{* * *} \\
(2.73)\end{array}$ \\
\hline $\begin{array}{l}\text { Spouse's Health Shocks } \\
\text { Acute health shock }\end{array}$ & & & & $\begin{array}{l}0.0157 \\
(1.49)\end{array}$ \\
\hline New chronic condition & & & & $\begin{array}{l}0.0068 \\
(1.29)\end{array}$ \\
\hline New mental health problem & & & & $\begin{array}{l}-0.0050 \\
(0.56)\end{array}$ \\
\hline Number of new IADLs & & & & $\begin{array}{l}-0.0004 \\
(0.08)\end{array}$ \\
\hline Number of new ADLs & & & & $\begin{array}{l}0.0052 \\
(1.29)\end{array}$ \\
\hline New Injury & & & & $\begin{array}{l}0.0096 \\
(1.14)\end{array}$ \\
\hline New Pain & & & & $\begin{array}{l}-0.0033 \\
(0.32)\end{array}$ \\
\hline Short hospitalization & & & & $\begin{array}{l}-0.0123 \\
(1.28)\end{array}$ \\
\hline Long hospitalization & & & & $\begin{array}{l}-0.0032 \\
(0.49)\end{array}$ \\
\hline Own baseline health & $\begin{array}{l}0.0150^{* * *} \\
(3.98)\end{array}$ & $\begin{array}{l}0.0144 * * * \\
(3.76)\end{array}$ & $\begin{array}{l}0.0146^{* * *} \\
(3.87)\end{array}$ & $\begin{array}{l}0.0143^{* * *} \\
(3.77)\end{array}$ \\
\hline Health Insurance & & & & \\
\hline Through Individual's Job & $\begin{array}{l}0.0124 \\
(1.15)\end{array}$ & $\begin{array}{l}0.0127 \\
(1.18)\end{array}$ & $\begin{array}{l}0.0141 \\
(1.34)\end{array}$ & $\begin{array}{l}0.0145 \\
(1.39)\end{array}$ \\
\hline Through Spouse’s Job & $\begin{array}{l}0.0394 * * * \\
(5.96)\end{array}$ & $\begin{array}{l}0.0399 * * * \\
(6.05)\end{array}$ & $\begin{array}{l}0.0381^{* * *} \\
(5.79)\end{array}$ & $\begin{array}{l}0.0379 * * * \\
(5.79)\end{array}$ \\
\hline Public Insurance & $\begin{array}{l}0.0184 \\
(1.44)\end{array}$ & $\begin{array}{l}0.0181 \\
(1.41)\end{array}$ & $\begin{array}{l}0.0162 \\
(1.30)\end{array}$ & $\begin{array}{l}0.0169 \\
(1.36)\end{array}$ \\
\hline
\end{tabular}




\begin{tabular}{lllll}
\hline Retiree Health Insurance & $0.0199^{* * *}$ & $0.0195^{* * *}$ & $0.0196^{* * *}$ & $0.0195^{* * *}$ \\
Available & $(2.79)$ & $(2.74)$ & $(2.78)$ & $(2.79)$ \\
& -0.0106 & -0.0106 & -0.0089 & -0.0083 \\
Missing Value on Retiree & & & & \\
Health Insurance & $(0.94)$ & $(0.94)$ & $(0.80)$ & $(0.75)$ \\
& & & \\
Job Characteristics & $-0.0064^{* * *}$ & $-0.0064^{* * *}$ & $-0.0060^{* * *}$ & $-0.0060^{* *}$ \\
Potential Experience & $(2.73)$ & $(2.74)$ & $(2.58)$ & $(2.51)$ \\
& $0.0016^{* * *}$ & $0.0016^{* * *}$ & $0.0015^{* * *}$ & $0.0015^{* * *}$ \\
Tenure on job & $(7.02)$ & $(7.03)$ & $(6.81)$ & $(6.86)$ \\
& 0.0009 & 0.0006 & 0.0008 & 0.0005 \\
Member of a union & $(0.17)$ & $(0.12)$ & $(0.15)$ & $(0.09)$ \\
& & & & \\
& 0.295 & 0.297 & 0.301 & 0.303 \\
Pseudo R-squared & 6854 & 6853 & 6853 & 6853 \\
Observations & & & & \\
& & & &
\end{tabular}

*indicates significance at the $10 \%$ level; **indicates significance at the $5 \%$ level; *** at $1 \%$ level. Standard errors are robust.

Note: Model also controls for squared, cubed, and quadratic earnings terms, full set of age dummies (52-60), age difference between spouse and self, education (some college, college, and missing), Hispanic, Other race, Black, and missing race, born in U.S, missing value on born in U.S., experience squared, and wave dummies. Due to perfect prediction with the "missing variable for union status," it is not in the model for women. 
Table 5. Weibull Hazard Model Results of the Husband's Risk of Retirement (time=age)

\begin{tabular}{|c|c|c|c|c|}
\hline & $\begin{array}{l}\text { Own } \\
\text { Financial }\end{array}$ & $\begin{array}{l}+ \text { Own } \\
\text { Health }\end{array}$ & $\begin{array}{l}\text { + Spouse's } \\
\text { Financial }\end{array}$ & $\begin{array}{l}\text { + Spouse's } \\
\text { Health }\end{array}$ \\
\hline $\begin{array}{l}\text { Peak Value of Social Security Wealth } \\
\text { (PV) }\end{array}$ & $\begin{array}{l}-0.1941^{* * *} \\
(9.95)\end{array}$ & $\begin{array}{l}-0.1912 * * * \\
(9.83)\end{array}$ & $\begin{array}{l}-0.1913 * * * \\
(9.85)\end{array}$ & $\begin{array}{l}-0.1920 * * * \\
(9.85)\end{array}$ \\
\hline $\begin{array}{l}\text { Expected present discounted value of } \\
\text { SS wealth (PDV) }\end{array}$ & $\begin{array}{l}-0.0023^{*} \\
(1.72)\end{array}$ & $\begin{array}{l}-0.0022 * \\
(1.70)\end{array}$ & $\begin{array}{l}-0.0024^{*} \\
(1.82)\end{array}$ & $\begin{array}{l}-0.0023^{*} \\
(1.76)\end{array}$ \\
\hline $\begin{array}{l}\text { Expected present discounted value of } \\
\text { DB wealth (PDV) }\end{array}$ & $\begin{array}{l}0.0019 * * * \\
(3.60)\end{array}$ & $\begin{array}{l}0.0019 * * * \\
(3.53)\end{array}$ & $\begin{array}{l}0.0019 * * * \\
(3.52)\end{array}$ & $\begin{array}{l}0.0019 * * * \\
(3.51)\end{array}$ \\
\hline Defined contribution wealth & $\begin{array}{l}0.0037 * * * \\
(4.41)\end{array}$ & $\begin{array}{l}0.0036^{* * *} \\
(4.22)\end{array}$ & $\begin{array}{l}0.0036 * * * \\
(4.15)\end{array}$ & $\begin{array}{l}0.0035^{* * *} \\
(4.00)\end{array}$ \\
\hline Annual earnings & $\begin{array}{l}-0.1281^{* * *} \\
(7.20)\end{array}$ & $\begin{array}{l}-0.1272 * * * \\
(7.12)\end{array}$ & $\begin{array}{l}-0.1283^{* * *} \\
(7.06)\end{array}$ & $\begin{array}{l}-0.1277 * * * \\
(7.00)\end{array}$ \\
\hline Lagged predicted health & $\begin{array}{l}-0.0250 \\
(0.50)\end{array}$ & $\begin{array}{l}-0.0718 \\
(1.41)\end{array}$ & $\begin{array}{l}-0.0697 \\
(1.37)\end{array}$ & $\begin{array}{l}-0.0722 \\
(1.42)\end{array}$ \\
\hline Age Difference & $\begin{array}{l}-0.0299 * * * \\
(3.98)\end{array}$ & $\begin{array}{l}-0.0291 * * * \\
(3.90)\end{array}$ & $\begin{array}{l}-0.0303 * * * \\
(3.97)\end{array}$ & $\begin{array}{l}-0.0312^{* * *} \\
(4.04)\end{array}$ \\
\hline Some College & $\begin{array}{l}-0.5338 * * * \\
(5.66)\end{array}$ & $\begin{array}{l}-0.5420 * * * \\
(5.75)\end{array}$ & $\begin{array}{l}-0.5422^{* * *} \\
(5.75)\end{array}$ & $\begin{array}{l}-0.5409 * * * \\
(5.71)\end{array}$ \\
\hline College & $\begin{array}{l}-0.7857 * * * \\
(5.42)\end{array}$ & $\begin{array}{l}-0.7853 * * * \\
(5.42)\end{array}$ & $\begin{array}{l}-0.7987 * * * \\
(5.53)\end{array}$ & $\begin{array}{l}-0.7935^{* * *} \\
(5.46)\end{array}$ \\
\hline Missing Education & $\begin{array}{l}-1.0175^{* * *} \\
(6.40)\end{array}$ & $\begin{array}{l}-1.0253^{* * *} \\
(6.48)\end{array}$ & $\begin{array}{l}-1.0278^{* * *} \\
(6.52)\end{array}$ & $\begin{array}{l}-1.0312^{* * *} \\
(6.53)\end{array}$ \\
\hline Hispanic & $\begin{array}{l}0.1062 \\
(0.58)\end{array}$ & $\begin{array}{l}0.0940 \\
(0.50)\end{array}$ & $\begin{array}{l}0.0974 \\
(0.52)\end{array}$ & $\begin{array}{l}0.1018 \\
(0.54)\end{array}$ \\
\hline $\begin{array}{l}\text { Health Insurance Through Individual's } \\
\text { Job }\end{array}$ & $\begin{array}{l}-0.3655^{* * * *} \\
(3.18)\end{array}$ & $\begin{array}{l}-0.3730 * * * \\
(3.24)\end{array}$ & $\begin{array}{l}-0.3775 * * * \\
(3.29)\end{array}$ & $\begin{array}{l}-0.3769 * * * \\
(3.28)\end{array}$ \\
\hline Health Insurance Through Spouse's Job & $\begin{array}{l}0.4484 * * * \\
(4.89)\end{array}$ & $\begin{array}{l}0.4394 * * * \\
(4.75)\end{array}$ & $\begin{array}{l}0.4070 * * * \\
(4.11)\end{array}$ & $\begin{array}{l}0.4047^{* * *} \\
(4.12)\end{array}$ \\
\hline Public Insurance & $\begin{array}{l}0.2816^{* * * *} \\
(2.60)\end{array}$ & $\begin{array}{l}0.2547 * * \\
(2.28)\end{array}$ & $\begin{array}{l}0.2539 * * \\
(2.27)\end{array}$ & $\begin{array}{l}0.2586^{* *} \\
(2.28)\end{array}$ \\
\hline Retiree Health Insurance Available & $\begin{array}{l}0.1178 \\
(1.59)\end{array}$ & $\begin{array}{l}0.1196 \\
(1.61)\end{array}$ & $\begin{array}{l}0.1209 \\
(1.63)\end{array}$ & $\begin{array}{l}0.1257^{*} \\
(1.69)\end{array}$ \\
\hline Retiree Health Insurance Missing & $\begin{array}{l}-1.3654 * * * \\
(11.28)\end{array}$ & $\begin{array}{l}-1.3627^{* * * *} \\
(11.22)\end{array}$ & $\begin{array}{l}-1.3665^{* * *} \\
(11.25)\end{array}$ & $\begin{array}{l}-1.3643^{* * *} \\
(11.20)\end{array}$ \\
\hline Potential Experience & $\begin{array}{l}0.2358^{* * *} \\
(8.54)\end{array}$ & $\begin{array}{l}0.2344 * * * \\
(8.49)\end{array}$ & $\begin{array}{l}0.2340 * * * \\
(8.48)\end{array}$ & $\begin{array}{l}0.2342^{* * *} \\
(8.48)\end{array}$ \\
\hline Experience $^{\wedge} 2$ & $\begin{array}{l}-0.0040^{* * *} \\
(8.62)\end{array}$ & $\begin{array}{l}-0.0040^{* * *} \\
(8.57)\end{array}$ & $\begin{array}{l}-0.0039 * * * \\
(8.55)\end{array}$ & $\begin{array}{l}-0.0040^{* * * *} \\
(8.54)\end{array}$ \\
\hline Tenure on job & $\begin{array}{l}0.0202 * * * \\
(8.88)\end{array}$ & $\begin{array}{l}0.0205 * * * \\
(9.01)\end{array}$ & $\begin{array}{l}0.0205^{* * *} \\
(8.98)\end{array}$ & $\begin{array}{l}0.0205 * * * \\
(8.96)\end{array}$ \\
\hline Member of a union & $\begin{array}{l}0.1543^{* *} \\
(2.54)\end{array}$ & $\begin{array}{l}0.1584^{* * *} \\
(2.60)\end{array}$ & $\begin{array}{l}0.1534^{* *} \\
(2.50)\end{array}$ & $\begin{array}{l}0.1612^{* * *} \\
(2.61)\end{array}$ \\
\hline Missing Union & $\begin{array}{l}0.6887 * * * \\
(6.95)\end{array}$ & $\begin{array}{l}0.6540 * * * \\
(5.94)\end{array}$ & $\begin{array}{l}0.6540 * * * \\
(5.87)\end{array}$ & $\begin{array}{l}0.5511^{* * * *} \\
(3.89)\end{array}$ \\
\hline
\end{tabular}




\begin{tabular}{|c|c|c|c|c|}
\hline Race not obtained & $\begin{array}{l}0.7773^{* * *} \\
(4.27)\end{array}$ & $\begin{array}{l}0.4129 * \\
(1.72)\end{array}$ & $\begin{array}{l}0.4231^{*} \\
(1.76)\end{array}$ & $\begin{array}{l}0.5451^{* *} \\
(2.20)\end{array}$ \\
\hline Black & $\begin{array}{l}0.0847 \\
(0.91)\end{array}$ & $\begin{array}{l}0.0935 \\
(1.01)\end{array}$ & $\begin{array}{l}0.0897 \\
(0.96)\end{array}$ & $\begin{array}{l}0.1008 \\
(1.09)\end{array}$ \\
\hline Other race & $\begin{array}{l}-0.2677 \\
(1.11)\end{array}$ & $\begin{array}{l}-0.2255 \\
(0.93)\end{array}$ & $\begin{array}{l}-0.2429 \\
(1.00)\end{array}$ & $\begin{array}{l}-0.2335 \\
(0.97)\end{array}$ \\
\hline Not born in US & $\begin{array}{l}0.0161 \\
(0.14)\end{array}$ & $\begin{array}{l}0.0053 \\
(0.04)\end{array}$ & $\begin{array}{l}0.0067 \\
(0.06)\end{array}$ & $\begin{array}{l}0.0040 \\
(0.03)\end{array}$ \\
\hline Location of birth unknown & $\begin{array}{l}0.6445 \\
(0.80)\end{array}$ & $\begin{array}{l}0.7178 \\
(0.92)\end{array}$ & $\begin{array}{l}0.7321 \\
(0.93)\end{array}$ & $\begin{array}{l}0.7137 \\
(0.91)\end{array}$ \\
\hline Acute health shock & & $\begin{array}{l}0.1431 \\
(1.25)\end{array}$ & $\begin{array}{l}0.1439 \\
(1.25)\end{array}$ & $\begin{array}{l}0.1475 \\
(1.28)\end{array}$ \\
\hline New chronic condition & & $\begin{array}{l}0.0845 \\
(1.36)\end{array}$ & $\begin{array}{l}0.0828 \\
(1.33)\end{array}$ & $\begin{array}{l}0.0891 \\
(1.43)\end{array}$ \\
\hline New Mental Health Problem & & $\begin{array}{l}0.0475 \\
(0.38)\end{array}$ & $\begin{array}{l}0.0458 \\
(0.37)\end{array}$ & $\begin{array}{l}0.0421 \\
(0.34)\end{array}$ \\
\hline Number of new IADLs & & $\begin{array}{l}0.0350 \\
(0.44)\end{array}$ & $\begin{array}{l}0.0329 \\
(0.42)\end{array}$ & $\begin{array}{l}0.0213 \\
(0.27)\end{array}$ \\
\hline Number of new ADLs & & $\begin{array}{l}0.1681^{* * *} \\
(3.06)\end{array}$ & $\begin{array}{l}0.1688^{* * *} \\
(3.07)\end{array}$ & $\begin{array}{l}0.1798^{* * *} \\
(3.24)\end{array}$ \\
\hline New Injury & & $\begin{array}{l}0.0173 \\
(0.10)\end{array}$ & $\begin{array}{l}0.0131 \\
(0.08)\end{array}$ & $\begin{array}{l}-0.0003 \\
(0.00)\end{array}$ \\
\hline New Pain & & $\begin{array}{l}0.0918 \\
(0.99)\end{array}$ & $\begin{array}{l}0.0911 \\
(0.98)\end{array}$ & $\begin{array}{l}0.0990 \\
(1.06)\end{array}$ \\
\hline Short hospitalization & & $\begin{array}{l}0.1730 \\
(1.41)\end{array}$ & $\begin{array}{l}0.1765 \\
(1.43)\end{array}$ & $\begin{array}{l}0.1922 \\
(1.56)\end{array}$ \\
\hline Long hospitalization & & $\begin{array}{c}0.0227 \\
(0.27)\end{array}$ & $\begin{array}{c}0.0230 \\
(0.27)\end{array}$ & $\begin{array}{c}0.0260 \\
(0.31)\end{array}$ \\
\hline $\begin{array}{l}\text { Spouse's expected present discounted } \\
\text { value of DB wealth (PDV) }\end{array}$ & & & $\begin{array}{l}0.0003 \\
(0.56)\end{array}$ & $\begin{array}{l}0.0004 \\
(0.78)\end{array}$ \\
\hline Spouse's defined contribution wealth & & & $\begin{array}{l}0.0030 * * * \\
(2.89)\end{array}$ & $\begin{array}{l}0.0030 * * * \\
(2.90)\end{array}$ \\
\hline Spouse's annual earnings & & & $\begin{array}{l}0.0070 \\
(0.33)\end{array}$ & $\begin{array}{l}0.0057 \\
(0.27)\end{array}$ \\
\hline Spouse acute health shock & & & & $\begin{array}{l}-0.2653 \\
(1.58)\end{array}$ \\
\hline Spouse's new chronic condition & & & & $\begin{array}{l}-0.1085^{*} \\
(1.71)\end{array}$ \\
\hline $\begin{array}{l}\text { Spouse's new mental health } \\
\text { Problem }\end{array}$ & & & & -0.0094 \\
\hline $\begin{array}{l}\text { Problem } \\
\text { Spouse's number of new IADLs }\end{array}$ & & & & $\begin{array}{c}(0.11) \\
0.0023 \\
(0.05)\end{array}$ \\
\hline Spouse's number of new ADLs & & & & $\begin{array}{l}-0.0615^{*} \\
(1.76)\end{array}$ \\
\hline Spouse's new Injury & & & & $\begin{array}{l}0.1184 \\
(1.32)\end{array}$ \\
\hline
\end{tabular}




\begin{tabular}{|c|c|c|c|c|}
\hline New Pain & & & & $\begin{array}{c}0.1492 \\
(0.96)\end{array}$ \\
\hline Spouse Short hospitalization & & & & $\begin{array}{l}-0.1750 \\
(1.32)\end{array}$ \\
\hline Spouse Long hospitalization & & & & $\begin{array}{l}0.0518 \\
(0.61)\end{array}$ \\
\hline Constant & $\begin{array}{l}-121.014^{* * *} \\
(18.57)\end{array}$ & $\begin{array}{l}-120.517^{* * * *} \\
(18.50)\end{array}$ & $\begin{array}{l}-120.546^{* * *} \\
(18.62)\end{array}$ & $\begin{array}{l}-120.680 * * * \\
(18.66)\end{array}$ \\
\hline Observations & 8447 & 8447 & 8447 & 8442 \\
\hline
\end{tabular}

* significant at $10 \%$; ** significant at $5 \%$; *** significant at $1 \%$

Note: All explanatory variables in the model appear in the table. 
Table 6. Weibull Hazard Model Results of the Husband's Risk of Retirement (time=age)

\begin{tabular}{|c|c|c|c|c|}
\hline & $\begin{array}{l}\text { Own } \\
\text { Financial }\end{array}$ & $\begin{array}{l}+ \text { Own } \\
\text { Health }\end{array}$ & $\begin{array}{l}\text { Spouse's } \\
\text { Financial }\end{array}$ & $\begin{array}{l}\text { Spouse's } \\
\text { Health }\end{array}$ \\
\hline Peak Value of Social Security & $-0.0768 * * *$ & $-0.0781^{* * *}$ & $-0.0823 * * *$ & $-0.0816 * * *$ \\
\hline Wealth (PV) & $(3.85)$ & $(3.91)$ & $(4.10)$ & $(4.07)$ \\
\hline Expected present discounted & $0.0027 *$ & $0.0029 *$ & 0.0015 & 0.0015 \\
\hline value of SS wealth (PDV) & $(1.72)$ & $(1.87)$ & $(0.89)$ & $(0.92)$ \\
\hline Expected present discounted & $0.0034 * * *$ & $0.0034 * * *$ & $0.0035^{* * *}$ & $0.0034 * * *$ \\
\hline value of DB wealth (PDV) & $(4.26)$ & $(4.24)$ & $(4.38)$ & $(4.12)$ \\
\hline Defined contribution wealth & $\begin{array}{l}0.0024 * * * \\
(2.76)\end{array}$ & $\begin{array}{l}0.0024 * * * \\
(2.68)\end{array}$ & $\begin{array}{l}0.0022^{* *} \\
(2.43)\end{array}$ & $\begin{array}{l}0.0023^{* * * *} \\
(2.65)\end{array}$ \\
\hline Annual earnings & $\begin{array}{l}-0.3730 * * * \\
(8.87)\end{array}$ & $\begin{array}{l}-0.3704^{* * *} \\
(8.83)\end{array}$ & $\begin{array}{l}-0.3645^{* * *} \\
(8.74)\end{array}$ & $\begin{array}{l}-0.3619 * * * \\
(8.61)\end{array}$ \\
\hline Lagged predicted health & $\begin{array}{l}0.1487 * * \\
(2.50)\end{array}$ & $\begin{array}{l}0.1337 * * \\
(2.22)\end{array}$ & $\begin{array}{l}0.1475 * * \\
(2.46)\end{array}$ & $\begin{array}{l}0.1432 * * \\
(2.39)\end{array}$ \\
\hline Age Difference & $\begin{array}{l}-0.0571^{* * *} \\
(4.11)\end{array}$ & $\begin{array}{l}-0.0581^{* * * *} \\
(4.21)\end{array}$ & $\begin{array}{l}-0.0590 * * * \\
(4.23)\end{array}$ & $\begin{array}{l}-0.0594^{* * *} \\
(4.21)\end{array}$ \\
\hline Some College & $\begin{array}{l}-0.5264^{* * *} \\
(3.85)\end{array}$ & $\begin{array}{l}-0.5379 * * * \\
(3.89)\end{array}$ & $\begin{array}{l}-0.5776^{* * *} \\
(4.19)\end{array}$ & $\begin{array}{l}-0.5713^{* * *} \\
(4.15)\end{array}$ \\
\hline College & $\begin{array}{l}-1.1431^{* * *} \\
(4.65)\end{array}$ & $\begin{array}{l}-1.1430 * * * \\
(4.63)\end{array}$ & $\begin{array}{l}-1.1822^{* * * *} \\
(4.83)\end{array}$ & $\begin{array}{c}-1.1826 * * * \\
(4.82)\end{array}$ \\
\hline Missing Education & $\begin{array}{l}-0.9256^{* * *} \\
(3.24)\end{array}$ & $\begin{array}{l}-0.9232^{* * *} \\
(3.23)\end{array}$ & $\begin{array}{l}-0.9602^{* * * *} \\
(3.39)\end{array}$ & $\begin{array}{l}-0.9666^{* * *} \\
(3.41)\end{array}$ \\
\hline Hispanic & $\begin{array}{l}0.1813 \\
(0.69)\end{array}$ & $\begin{array}{l}0.1912 \\
(0.73)\end{array}$ & $\begin{array}{l}0.1891 \\
(0.73)\end{array}$ & $\begin{array}{l}0.1943 \\
(0.74)\end{array}$ \\
\hline Health Insurance Through & -0.1587 & -0.1492 & -0.1511 & -0.1493 \\
\hline Individual's Job & $(0.95)$ & $(0.89)$ & $(0.90)$ & $(0.88)$ \\
\hline Health Insurance Through & $0.5993 * * *$ & $0.6196 * * *$ & $0.5919 * * *$ & $0.5864 * * *$ \\
\hline Spouse’s Job & $(6.83)$ & $(7.02)$ & $(6.65)$ & $(6.55)$ \\
\hline Public Insurance & $\begin{array}{l}0.2722 * \\
(1.70)\end{array}$ & $\begin{array}{l}0.2667^{*} \\
(1.66)\end{array}$ & $\begin{array}{l}0.2797^{*} \\
(1.74)\end{array}$ & $\begin{array}{l}0.2861 * \\
(1.79)\end{array}$ \\
\hline Retiree Health Insurance & $0.3175 * * *$ & $0.3136 * * *$ & $0.3214 * * *$ & $0.3121 * * *$ \\
\hline Available & $(3.07)$ & $(3.01)$ & (3.01) & (2.93) \\
\hline Retiree Health Insurance & $-0.3635 * *$ & $-0.3608 * *$ & $-0.3525 * *$ & $-0.3548 * *$ \\
\hline Missing & $(2.11)$ & $(2.10)$ & $(2.01)$ & $(2.01)$ \\
\hline Potential Experience & $\begin{array}{l}0.3573 * * * \\
(5.97)\end{array}$ & $\begin{array}{l}0.3598 * * * \\
(5.99)\end{array}$ & $\begin{array}{l}0.3630^{* * *} \\
(6.06)\end{array}$ & $\begin{array}{l}0.3658 * * * \\
(6.06)\end{array}$ \\
\hline Experience $\wedge 2_{2}$ & $\begin{array}{l}-0.0062 * * * \\
(6.07)\end{array}$ & $\begin{array}{l}-0.0062 * * * \\
(6.10)\end{array}$ & $\begin{array}{l}-0.0062^{* * *} \\
(6.16)\end{array}$ & $\begin{array}{c}-0.0063 * * * \\
(6.15)\end{array}$ \\
\hline Tenure on job & $\begin{array}{l}0.0186 * * * \\
(5.01)\end{array}$ & $\begin{array}{l}0.0188 * * * \\
(5.03)\end{array}$ & $\begin{array}{l}0.0188 * * * \\
(4.94)\end{array}$ & $\begin{array}{l}0.0187 * * * \\
(4.90)\end{array}$ \\
\hline Member of a union & $\begin{array}{l}-0.1044 \\
(1.14)\end{array}$ & $\begin{array}{l}-0.1154 \\
(1.26)\end{array}$ & $\begin{array}{l}-0.1011 \\
(1.11)\end{array}$ & $\begin{array}{l}-0.1053 \\
(1.15)\end{array}$ \\
\hline Missing Union & $\begin{array}{l}1.6975 * * * \\
(2.83)\end{array}$ & $\begin{array}{l}1.7570 * * * \\
(3.01)\end{array}$ & $\begin{array}{l}1.7790^{* * * *} \\
(3.01)\end{array}$ & $\begin{array}{l}1.7681^{* * *} \\
(3.01)\end{array}$ \\
\hline
\end{tabular}




\begin{tabular}{|c|c|c|c|c|}
\hline Black & $\begin{array}{l}-0.0874 \\
(0.71)\end{array}$ & $\begin{array}{l}-0.0762 \\
(0.62)\end{array}$ & $\begin{array}{l}-0.0750 \\
(0.61)\end{array}$ & $\begin{array}{l}-0.0685 \\
(0.56)\end{array}$ \\
\hline Other race & $\begin{array}{l}-0.5476 \\
(1.43)\end{array}$ & $\begin{array}{l}-0.5640 \\
(1.45)\end{array}$ & $\begin{array}{l}-0.5544 \\
(1.43)\end{array}$ & $\begin{array}{l}-0.5439 \\
(1.39)\end{array}$ \\
\hline Not born in US & $\begin{array}{l}0.1638 \\
(1.00)\end{array}$ & $\begin{array}{l}0.1599 \\
(0.96)\end{array}$ & $\begin{array}{l}0.1351 \\
(0.81)\end{array}$ & $\begin{array}{l}0.1207 \\
(0.72)\end{array}$ \\
\hline Acute health shock & & $\begin{array}{l}0.2826^{*} \\
(1.71)\end{array}$ & $\begin{array}{l}0.2509 \\
(1.51)\end{array}$ & $\begin{array}{l}0.2577 \\
(1.54)\end{array}$ \\
\hline New chronic condition & & $\begin{array}{l}0.0187 \\
(0.25)\end{array}$ & $\begin{array}{l}0.0114 \\
(0.15)\end{array}$ & $\begin{array}{l}0.0075 \\
(0.10)\end{array}$ \\
\hline New Mental Health Problem & & $\begin{array}{l}0.1833 \\
(1.54)\end{array}$ & $\begin{array}{l}0.1944 \\
(1.63)\end{array}$ & $\begin{array}{l}0.1889 \\
(1.56)\end{array}$ \\
\hline Number of new IADLs & & $\begin{array}{l}-0.0133 \\
(0.15)\end{array}$ & $\begin{array}{l}-0.0157 \\
(0.18)\end{array}$ & $\begin{array}{l}-0.0045 \\
(0.05)\end{array}$ \\
\hline Number of new ADLs & & $\begin{array}{l}0.0293 \\
(0.38)\end{array}$ & $\begin{array}{l}0.0258 \\
(0.33)\end{array}$ & $\begin{array}{c}0.0244 \\
(0.31)\end{array}$ \\
\hline New Injury & & $\begin{array}{l}0.3157^{*} \\
(1.66)\end{array}$ & $\begin{array}{l}0.3283^{*} \\
(1.72)\end{array}$ & $\begin{array}{l}0.3429 * \\
(1.85)\end{array}$ \\
\hline New Pain & & $\begin{array}{l}-0.0897 \\
(0.79)\end{array}$ & $\begin{array}{l}-0.0766 \\
(0.67)\end{array}$ & $\begin{array}{l}-0.0760 \\
(0.67)\end{array}$ \\
\hline Short hospitalization & & $\begin{array}{l}-0.1683 \\
(0.98)\end{array}$ & $\begin{array}{l}-0.1648 \\
(0.96)\end{array}$ & $\begin{array}{l}-0.1712 \\
(0.99)\end{array}$ \\
\hline Long hospitalization & & $\begin{array}{l}-0.0756 \\
(0.68)\end{array}$ & $\begin{array}{l}-0.0585 \\
(0.53)\end{array}$ & $\begin{array}{l}-0.0410 \\
(0.37)\end{array}$ \\
\hline $\begin{array}{l}\text { Spouse's expected present } \\
\text { discounted value of DB wealth (PDV) }\end{array}$ & & & $\begin{array}{l}0.0011 \\
(1.25)\end{array}$ & $\begin{array}{l}0.0012 \\
(1.47)\end{array}$ \\
\hline Spouse's defined contribution wealth & & & $\begin{array}{l}0.0067 * * * \\
(4.12)\end{array}$ & $\begin{array}{l}0.0066^{* * *} \\
(4.12)\end{array}$ \\
\hline Spouse's annual earnings & & & $\begin{array}{l}0.0032 \\
(0.20)\end{array}$ & $\begin{array}{l}0.0034 \\
(0.21)\end{array}$ \\
\hline Spouse acute health shock & & & & $\begin{array}{l}0.0156 \\
(0.12)\end{array}$ \\
\hline Spouse’s new chronic condition & & & & $\begin{array}{l}0.0712 \\
(0.91)\end{array}$ \\
\hline Spouse's new mental health problem & & & & $\begin{array}{l}0.0258 \\
(0.16)\end{array}$ \\
\hline Spouse's number of new IADLs & & & & $\begin{array}{l}0.0261 \\
(0.32)\end{array}$ \\
\hline Spouse's number of new ADLs & & & & $\begin{array}{l}0.0598 \\
(0.88)\end{array}$ \\
\hline Spouse's new Injury & & & & $\begin{array}{l}0.1439 \\
(1.24)\end{array}$ \\
\hline New Pain & & & & $\begin{array}{l}-0.1761 \\
(0.92)\end{array}$ \\
\hline Spouse Short hospitalization & & & & $\begin{array}{l}-0.3248 * \\
(1.74)\end{array}$ \\
\hline
\end{tabular}




\begin{tabular}{lllll}
\hline Spouse Long hospitalization & & & & -0.0933 \\
& & & & $(0.95)$ \\
Constant & $-124.944 * * *$ & $-125.336 * * *$ & $-126.270 * * *$ & $-127.169 * * *$ \\
& $(10.31)$ & $(10.35)$ & $(10.53)$ & $(10.55)$ \\
Observations & 6854 & 6853 & 6853 & 6853 \\
\hline
\end{tabular}

* significant at $10 \%$; ** significant at $5 \%$; *** significant at $1 \%$

Note: All explanatory variables in the model appear in the table. 
Table 7. Linear Regression of Change in Hours Worked Per Week Among Workers (calculated as Average Weekly Hours $_{t}-$ Average Weekly Hours $_{t-1}$ )

\begin{tabular}{|c|c|c|}
\hline Variable Description & $\begin{array}{l}\text { MEN } \\
\text { coeff. (s.e.) }\end{array}$ & $\begin{array}{l}\text { WOMEN } \\
\text { coeff. (s.e.) }\end{array}$ \\
\hline \multicolumn{3}{|l|}{ Own/Couple's Financial Incentives } \\
\hline \multirow{2}{*}{$\begin{array}{l}\text { Peak Value of Social Security Wealth } \\
\text { (PV) }\end{array}$} & $0.0438 *$ & 0.0279 \\
\hline & (1.79) & $(0.93)$ \\
\hline \multirow{2}{*}{$\begin{array}{l}\text { Expected present discounted value of SS } \\
\text { wealth (PDV) }\end{array}$} & $-0.0096 * *$ & 0.0014 \\
\hline & $(2.15)$ & $(0.25)$ \\
\hline \multirow{2}{*}{$\begin{array}{l}\text { Expected present discounted value of } \\
\text { DB wealth (PDV) }\end{array}$} & -0.0015 & $-0.0053^{*}$ \\
\hline & $(0.55)$ & $(1.72)$ \\
\hline Defined contribution wealth & $\begin{array}{l}-0.0083 \\
(1.35)\end{array}$ & $\begin{array}{l}0.0089 * * * \\
(2.70)\end{array}$ \\
\hline Annual earnings & $\begin{array}{l}0.6440 * * * \\
(5.24)\end{array}$ & $\begin{array}{l}1.9923 * * * \\
(5.38)\end{array}$ \\
\hline Net worth quartile 1 & $\begin{array}{l}0.8481^{*} \\
(1.84)\end{array}$ & $\begin{array}{c}0.4194 \\
(0.88)\end{array}$ \\
\hline Net worth quartile 2 & $\begin{array}{l}0.4990 \\
(1.24)\end{array}$ & $\begin{array}{l}0.4250 \\
(1.08)\end{array}$ \\
\hline Net worth quartile 3 & $\begin{array}{l}0.6365^{*} \\
(1.75)\end{array}$ & $\begin{array}{l}-0.0652 \\
(0.18)\end{array}$ \\
\hline Liquid assets quartile 1 & $\begin{array}{l}0.0345 \\
(0.09)\end{array}$ & $\begin{array}{l}0.9169 * * \\
(2.09)\end{array}$ \\
\hline Liquid assets quartile 2 & $\begin{array}{l}0.4232 \\
(1.21)\end{array}$ & $\begin{array}{l}0.3700 \\
(1.01)\end{array}$ \\
\hline Liquid assets quartile 3 & $\begin{array}{l}-0.3169 \\
(0.96)\end{array}$ & $\begin{array}{l}0.3056 \\
(0.88)\end{array}$ \\
\hline \multicolumn{3}{|l|}{ Own Health Shocks } \\
\hline Acute health shock & $\begin{array}{l}0.0955 \\
(0.15)\end{array}$ & $\begin{array}{l}-2.2140^{*} \\
(1.74)\end{array}$ \\
\hline New chronic condition & $\begin{array}{l}0.3787 \\
(1.30)\end{array}$ & $\begin{array}{l}-0.2873 \\
(0.93)\end{array}$ \\
\hline New mental health problem & $\begin{array}{l}-0.7891 \\
(1.25)\end{array}$ & $\begin{array}{l}-1.7282 * * * \\
(3.37)\end{array}$ \\
\hline Number of new IADLs & $\begin{array}{l}0.2649 \\
(0.55)\end{array}$ & $\begin{array}{l}0.2414 \\
(0.60)\end{array}$ \\
\hline Number of new ADLs & $\begin{array}{l}-0.7551 \\
(1.49)\end{array}$ & $\begin{array}{l}-0.6442 \\
(1.36)\end{array}$ \\
\hline New Injury & $\begin{array}{l}-3.4034 * * * \\
(2.89)\end{array}$ & $\begin{array}{l}-1.9474 \\
(1.53)\end{array}$ \\
\hline New Pain & 0.1432 & -0.0253 \\
\hline
\end{tabular}


Short hospitalization

(0.33)

(0.06)

0.2555

0.5436

Long hospitalization

(0.42)

(0.78)

$-0.8991^{* *}$

$-0.4525$

Spouse's Financial Incentives

(2.07)

(0.93)

Expected present discounted value of

0.0015

0.0053

DB wealth (PDV)

(0.35)

0.0036

(1.43)

Defined Contribution wealth

(1.03)

$-0.0208$

$-0.0321$

(1.07)

Annual earnings

(0.17)

$-0.2988 * *$

(2.24)

\section{Spouse's health shocks}

Acute health shock

$-0.1118$

0.3689

New chronic condition

(0.18)

$-0.0260$

$(0.67)$

(0.09)

New mental health problem

0.0270

(0.07)

Number of new IADLs

$-0.5854^{* *}$

$-0.1780$

(0.60)

$-0.0084$

$(0.01)$

0.3754

(2.03)

0.2049

(1.09)

Number of new ADLs

(1.00)

New Injury

$-0.4044$

(0.53)

$-0.8148 *$

(1.93)

Short hospitalization

0.1631

(0.29)

Long hospitalization

$-0.0803$

(0.21)

$-0.1074$

Own baseline health

(0.39)

0.0498

$(0.22)$

$-0.1985$

$(0.28)$

0.0237

(0.06)

$-0.4550$

(0.76)

$-0.2337$

(0.64)

0.0992

(0.42)

Health Insurance

Through Individual's Job

$3.3688 * * *$

(5.93)

$1.1997^{* *}$

(2.27)

$1.1424 * *$

$1.9794 * * *$

(3.44)

Through Spouse’s Job

(2.12)

$-0.0391$

(0.15)

$1.5383^{* * *}$

Public Insurance

(3.71)

$-0.0057$

(0.01)

$-0.3215$

(1.12)

$-0.7111$

$-0.4667$

(1.43) 
Job Characteristics

Potential Experience

0.2866

$-0.2756 * *$

Tenure on job

(1.56)

(2.17)

$-0.0201 *$

$-0.0471 * * *$

(1.86)

(3.47)

Member of a union

0.2516

$0.6844 * *$

(0.92)

(2.41)

Union missing

$-1.8713$

$5.3771 * * *$

(0.75)

(3.51)

Demographics

Race not obtained

\section{$3.3821 * *$}

0.0000

African American

(2.18)

(.)

0.0675

$-0.2171$

(0.15)

$(0.48)$

Other race

$1.9302 * * *$

$-0.1091$

(2.71)

(0.11)

0.6249

$-1.8122 *$

(0.97)

(1.74)

$-0.6106$

$-1.5393 * * *$

Not born in the U.S.

(1.27)

(2.63)

Constant

$-17.7727 * * *$

$-0.5775$

(2.64)

Observations

8438

(0.17)

6852

R-squared

0.04

0.04

Robust t statistics in parentheses

* significant at $10 \%$; ** significant at $5 \%$; *** significant at $1 \%$

Note: A positive value of change in hours means the workers increased their hours worked between $\mathrm{t}-1$ and $\mathrm{t}$. Thus a positive coefficient on an $\mathrm{X}$ variable is interpreted as causing one to increase their hours worked from the previous wave. Model also controls for squared, cubed, and quadratic earnings terms, full set of age dummies (52-60), age difference between spouse and self, education (some college, college, and missing), experience squared, and wave dummies. 
Table 8. Health and Social Security Benefit Counterfactuals and the predicted probability of retirement ${ }^{1}$

Description of the Scenario

Men

Women

Probability/Mean Predicted Probability

(Absolute \%pt difference)

[\% change from baseline prediction]

Unadjusted probability of retirement ${ }^{2}$
0.114
0.10
(0.187)

Main results: Predicted Probability of retirement ${ }^{1}$

0.124

0.103

(0.187)

SOCIAL SECURITY SCENARIOS

A.) Reduce Social Security Wealth by $13.1 \%$

0.124

0.103

(0)

(0)

[0]

[0]

HEALTH SCENARIOS: Improvements

No new health shocks

Individual

0.116

0.103

$(-.008)$

(0)

[-6.5\%]

[0]

Spouse

0.120

0.100

$(-.004)$

$(-0.003)$

[-3.2\%]

[-2.9\%]

Neither

0.112

0.100

$(-.012)$

[-9.7\%]

$(-.003)$

[-2.9\%]

Medical advances

.123

.105

$(-.001)$

(.002)

[-0.8\%]

[1.9\%]

New treatment for depression/psychological problems

$\begin{array}{ll}0.120 & 0.104 \\ (-.004) & (0.001) \\ {[-3.2 \%]} & {[.97 \%]}\end{array}$


Table 8 (Continued). Health and Social Security Benefit Counterfactuals and the predicted probability of retirement ${ }^{1}$

Description of the Scenario

Men

Women

Probability/Predicted Probability

(Absolute \%pt difference)

[\% change from baseline prediction]

HEALTH SCENARIOS: Declines

Individual $^{3}$

0.181

0.092

(.057)

$(-.011)$

[46.0\%]

[-10.7\%]

Spouse $^{4}$

0.145

.103

(.021)

(0)

[16.9\%]

[0]

Both

.209

.092

(.085)

$(-.011)$

[68.5\%]

[-10.7\%]

Onset of Obesity-related conditions

Individual

.261

(.137)

[110.5\%]

Spouse

.123

(.001)

[-0.8\%]

0.074

$(-.029)$

[-23.4\%]

0.143

Both

0.260

0.104

(.136)

(.001)

[110\%]

[0.97\%]

Number of observation

8435

6851

\footnotetext{
${ }^{1}$ Fully adjusted models for men and women, controlling for own financial, own health shocks, spouse financial, spouse health shocks, health insurance, education, age dummies, race and ethnicity, and year dummies (predicted from results presented in Columns 4 of Table 3 and 4, respectively). In addition, the predicted probability using individual health shocks was nearly identical to the main results out to the $4^{\text {th }}$ decimal place.

${ }^{2}$ This is the person-wave risk. On an individual level it differs (see Table 2). Of all individuals in the data set, $35.8 \%$ of men and $28.8 \%$ of wives retired at some point in the observation period.

${ }^{3}$ Onset of diabetes, heart attack, two ADL limitations for men. New cancer, new arthritis, new pain for women.

${ }^{4}$ Wife had long stay in the hospital. Did not change husband's health as nothing was significant.
} 


\section{Appendix A: Calculation of Social Security Incentives}

The peak-value variable of forward-looking incentives was created following Coile and Gruber, 2007 (and the text in this section also draws heavily from Coile and Gruber, 2007). We adapted it for the purposes of this paper because we calculated it for persons who are single and married separately, used a 3 percent discount rate and more flexible assumptions about the retirement ages of each member in a couple in the calculation of expected net present discounted value of retirement wealth, instead of assuming that the spouse retires at age 62. The four steps were as follows:

First, we used data from the Social Security Administration and the HRS to create AIME (Average Indexed Monthly Earnings). This required information on historical earnings, current earnings, birth year, age, and Social Security Administration rules (such as taking the top 35 years of earnings, etc. For example, AIME is calculated based on the highest 35 years of income. If the individual works for one more year with high income, the high income will replace the lower ones from earlier years and result in a higher AIME. When earnings were missing from the SSA data, we used self-reported earnings from the HRS (we calculated earnings using the variables from RAND on annual earnings, and when this value was missing, we calculated earnings using average hours per week, or $r^{*}$ jhours $r^{*}$ jweeks $r^{*}$ wgihr). We indexed AIME to age 60 .

Second, we created the Primary Insurance Amount (PIA) associated with each retirement age. The PIA is calculated using the AIME and two bend points. PIA is the $90 \%$ of the AIME up to the first bend point plus the 32\% of the AIME between the first and second bend points, and the $15 \%$ of the AIME after the second bend point. 
Third, we calculated Expected Net Present Discounted Value of Social Security Wealth (PDV). To calculate this, we used PIA at the interview year, spouse's PIA at the interview year, gender, spouse's gender, birth year, spouse's birth year, age at the beginning of the interview year, and spouse's age at the beginning of the interview year.

Initially we followed the same method suggested in Coile 2004a: "The next step is to compute the expected net present discounted value (PDV) of SSW associated with each retirement date.” Our methodology for doing so is described in Coile and Gruber (2001). For single workers, this is simply a sum of future benefits, discounted by time preference rates and survival probabilities. For married workers it is more complicated, since we must include dependent spouse and survivor benefits and account for the joint likelihood of survival of the worker and dependent.

Unlike Coile (Coile, 2004b), who used 6\%, we used a 3\% discount rate and survival probabilities from the birth year- and sex-specific U.S. life tables (Sass, Sun and Webb, 2001). We calculated PDV for married couples separately. We create PDV for each age combination from 62 to 70 (e.g. husband at 62, wife at 65, etc.). There are 4 possible combinations; wife younger than 62; between 62 and 70; husband younger than 62; between 62 and 70 . The rules are the same as singles. For example, if the husband is 66 today and the wife is 60 , then the current couple's expected net present discounted value (PDV) of social security at the HRS interview date will assume the value in which the husband claims at 66 and the wife claims at 62.

In Coile’s work, (2004b) she suggests calculating each spouses incentive to work conditional on the other spouse retiring at age 62. As such, the husband and wife will have slightly different PDVs (corr 0.97). Then one can take the simple average to get the couple-level 
PDV. Our approach was more flexible because we calculated the PDV for every possible combination of the husband's and wife's claiming ages. Instead of asking the spouse to retire at only 62, as mentioned above we calculated the PDV by allowing the spouse to retire at any age between 62 to 70. Thus, we capture the PDV of Social Security at actual claiming ages of both spouses. The husband and the wife will have exactly the same PDV.

Fourth, we created the peak value retirement incentive measure (PV) of each individual in the couple. PV is simply the value of continuing to work until the year when Social Security wealth is maximized. In other words, one finds the PDV of retirement wealth at its maximum value in the future minus the PDV if one retired today (Coile, 2004b). Coile and Gruber (2007) showed that this incentive measure was superior to using simply variations in wages or the option value approaches of Stock and Wise (Stock \& Wise, 1990). 


\section{Appendix B: Calculation of Present Discounted Value of Defined Benefit Pension Wealth}

The HRS provides self-reported information on benefits from the current job (if employed), last job (if unemployed), and the first time they are interviewed, they are asked about any significant past job that lasted longer than 5 years. Individuals also provide pension information from any job they leave during the panel. Respondents report benefits from these plans in one of two possible ways - as a benefit amount or as a percentage of final pay ("formula"). If they state the former, we assume that benefits gown at a 1 percent real wage growth rate. If they state the latter, current pay is projected forward to the expected retirement age using the same $1 \%$ real wage growth rate. For job they have already left, the self-reported value of final pay is used. We assume that people are shortsighted and do not take into account inflation in reporting the final pay and future benefits. Hence the benefit amounts calculated are in nominal dollars of the reporting year (1992 - 2006).

In a number of cases, respondents report being covered by a defined benefit plan, but do not report any other information about the plan. In these cases, benefits expected or currently received from current job are imputed. Benefits from past jobs are not imputed, as failure to report amounts may signal that respondent is no longer eligible to receive benefits from that source. Imputation is done through the hot-decking procedure by earnings brackets and cohort. In a number of cases, information on expected retirement age (or the age when respondents will start collecting benefits) is missing. In these cases, we assign them a value of age 62.

To calculate the total defined benefit pension "wealth,” each source is first top-coded at 1 percent to correct the irregularities in self-reported data (e.g. in some cases individuals report unusually high benefits). The expected benefits are converted to the dollars in the expected retirement year using 3.6 percent inflation rate, corresponding to the long-term inflation 
projection. A nominal interest rate of 7.01 percent is then used to estimate the discounted value of the benefits at the expected retirement age, under the assumption that benefits are paid at the beginning of each period (the nominal interest rate is approximated as the sum of long term real interest rate of 3.41 percent and the long term inflation projection). The discounted value of the benefits calculation incorporates individual survival probabilities adopted from the Social Security Cohort Mortality Tables (Board of Trustees, 2004). An implicit assumption is made that everyone in the sample survives till the age of 61 . No survivor benefit payments are assumed.

To make the defined benefit pension calculations comparable with defined contribution plan balances, the value of defined benefit pension "wealth" at the expected retirement age is discounted back to the reporting year, using the same nominal interest rates. To account for the fact that people continue accumulating pension wealth through the date of retirement, the present discounted value of the benefit from the current job is prorated on the basis of tenure to date and the expected retirement age. Take, for example, the case of a 55-year-old who expects defined benefit wealth of $\$ 100,000$ at age 65 . This worker started working for the company at 45 , and therefore has completed only 50 percent of his 20-year (45-65) tenure. Finally, the prorated discounted value of defined benefit "wealth" is converted to 2006 dollars using the CPI index to account for inflation between the reporting date and 2006.

As a last step, the PDV of defined benefit pension wealth is summed across all plans from current and previous jobs. Household defined benefit pension "wealth" is computed by summing across the head and spouse. 


\section{Appendix C: Calculations of Defined Contribution and IRA Wealth}

Defined contribution wealth includes self-reported assets on all employer-sponsored accounts from past and present jobs. In some instances, respondents report that they transferred the balance to an IRA or cashed the benefits. In this case, balance of the corresponding account is excluded from the calculation. Defined contribution wealth is top-coded at one percent to reduce the impact of reporting errors on mean values.

Similar to defined benefit pension plans, for some defined contribution plans information of account balances is missing. In these instances, missing information is imputed using hotdecking procedure by earnings bracket. Imputations are performed only for plans from current jobs.

To calculate the household value of defined contribution plans, the total assets on employer-sponsored defined contribution accounts are summed up across head and spouse. Household IRA/Keogh wealth from the RAND file is added to capture the total defined contribution pension balances. For most people, IRA accumulations are simply the balances transferred from a past employer-sponsored defined contribution plan. 


\begin{tabular}{|c|c|c|}
\hline Variable & $\begin{array}{l}\text { MEN } \\
\text { (coeff/s.e.) }\end{array}$ & $\begin{array}{l}\text { WOMEN } \\
\text { (coeff/s.e.) }\end{array}$ \\
\hline Ever had a heart attack & $\begin{array}{l}0.3595 * * * \\
(3.47)\end{array}$ & $\begin{array}{l}0.6121 * * * \\
(3.24)\end{array}$ \\
\hline Stroke in past two years & $\begin{array}{l}0.2637^{* * *} \\
(3.19)\end{array}$ & $\begin{array}{l}0.1507 \\
(1.16)\end{array}$ \\
\hline Cancer in past two years & $\begin{array}{l}0.4232^{* * *} \\
(7.71)\end{array}$ & $\begin{array}{l}0.3232^{* * *} \\
(6.48)\end{array}$ \\
\hline Arthritis currently & $\begin{array}{l}0.1786^{* * *} \\
(6.95)\end{array}$ & $\begin{array}{l}0.2777 * * * \\
(9.88)\end{array}$ \\
\hline Lung disease in past two years & $\begin{array}{l}0.6798^{* * *} \\
(11.44)\end{array}$ & $\begin{array}{l}0.4484^{* * *} \\
(6.86)\end{array}$ \\
\hline Heart condition in past two years & $\begin{array}{l}0.3566 * * * \\
(9.40)\end{array}$ & $\begin{array}{l}0.4713^{* * *} \\
(9.28)\end{array}$ \\
\hline Ever had Angina & $\begin{array}{l}0.3243 * * * \\
(4.14)\end{array}$ & $\begin{array}{l}0.3020^{* * *} \\
(2.82)\end{array}$ \\
\hline High blood pressure currently & $\begin{array}{l}0.3777 * * * \\
(15.22)\end{array}$ & $\begin{array}{l}0.4146^{* * *} \\
(14.85)\end{array}$ \\
\hline Ever had diabetes & $\begin{array}{l}0.5496 * * * \\
(15.28)\end{array}$ & $\begin{array}{l}0.6242^{* * *} \\
(13.44)\end{array}$ \\
\hline Incontinence in past two years & $\begin{array}{l}0.1217^{*} \\
(1.93)\end{array}$ & $\begin{array}{l}0.0435 \\
(1.28)\end{array}$ \\
\hline Missing value on incontinence & $\begin{array}{l}0.6149 * * * \\
(3.42)\end{array}$ & $\begin{array}{l}0.9520^{* * *} \\
(4.47)\end{array}$ \\
\hline $\begin{array}{l}\text { Depression screen positive } \\
\text { (CESD8 }>4 \text { ) }\end{array}$ & $0.1087^{* * *}$ & $0.1205^{* * *}$ \\
\hline & (10.78) & $(13.16)$ \\
\hline Recent psychological Problem & $\begin{array}{l}0.2000^{* * *} \\
(4.00)\end{array}$ & $\begin{array}{l}0.2393^{* * *} \\
(5.68)\end{array}$ \\
\hline Cognitive ability score & $\begin{array}{l}-0.0249 * * * \\
(6.55)\end{array}$ & $\begin{array}{l}-0.0214^{* * *} \\
(5.23)\end{array}$ \\
\hline Missing cognitive ability score & $\begin{array}{l}-0.4408^{* * *} \\
(4.97)\end{array}$ & $\begin{array}{l}-0.4530^{* * *} \\
(4.66)\end{array}$ \\
\hline $\begin{array}{l}\text { Number of current ADL limitations } \\
\text { due to health problem }\end{array}$ & $\begin{array}{l}0.2754^{* * *} \\
(7.72)\end{array}$ & $\begin{array}{l}0.2645^{* * *} \\
(6.38)\end{array}$ \\
\hline $\begin{array}{l}\text { Subjective probability of living to } \\
\text { age } 75 \text {, quartile } 1\end{array}$ & $0.7141^{* * *}$ & $0.4963 * * *$ \\
\hline $\begin{array}{l}\text { Subjective probability of living to } \\
\text { age } 75 \text {, quartile } 2\end{array}$ & $\begin{array}{l}(9.17) \\
0.4164^{* * *}\end{array}$ & $\begin{array}{l}(5.12) \\
0.4070^{* * *}\end{array}$ \\
\hline
\end{tabular}




\begin{tabular}{|c|c|c|}
\hline & $(12.70)$ & $(12.34)$ \\
\hline \multirow{2}{*}{$\begin{array}{l}\text { Subjective probability of living to } \\
\text { age } 75 \text {, quartile } 3\end{array}$} & $0.1017 * * *$ & $0.1348 * * *$ \\
\hline & $(2.80)$ & (3.73) \\
\hline \multirow{2}{*}{$\begin{array}{l}\text { Missing subjective probability of } \\
\text { survival }\end{array}$} & $0.4787 * * *$ & $0.5389 * * *$ \\
\hline & $(13.35)$ & $(10.90)$ \\
\hline \multirow[t]{2}{*}{ Frequently bothered by pain } & $0.5209 * * *$ & $0.6050 * * *$ \\
\hline & $(16.16)$ & $(17.74)$ \\
\hline \multirow[t]{2}{*}{ Any injury } & 0.1020 & 0.0289 \\
\hline & $(1.30)$ & $(0.28)$ \\
\hline \multirow[t]{2}{*}{ Age } & 0.0084 & 0.0038 \\
\hline & $(0.24)$ & $(0.09)$ \\
\hline \multirow[t]{2}{*}{ Age squared } & -0.0001 & -0.0001 \\
\hline & $(0.32)$ & $(0.41)$ \\
\hline \multirow[t]{2}{*}{ Difference in age from spouse } & 0.0032 & 0.0036 \\
\hline & $(1.11)$ & $(1.04)$ \\
\hline \multirow[t]{2}{*}{ completed high school } & $0.0984 * * *$ & $0.1288 * * *$ \\
\hline & $(3.21)$ & $(3.54)$ \\
\hline \multirow[t]{2}{*}{ Completed some college } & $-0.0671 * *$ & 0.0147 \\
\hline & $(2.00)$ & $(0.38)$ \\
\hline \multirow[t]{2}{*}{ Completed college } & $-0.1761 * * *$ & $-0.1562 * * *$ \\
\hline & $(4.57)$ & (3.38) \\
\hline \multirow[t]{2}{*}{ Race not obtained } & -0.7390 & 0.3184 \\
\hline & $(1.22)$ & $(1.20)$ \\
\hline \multirow[t]{2}{*}{ African American } & $0.2875 * * *$ & $0.5239 * * *$ \\
\hline & $(7.02)$ & $(12.77)$ \\
\hline \multirow[t]{2}{*}{ Other Non-White Race } & 0.0983 & $0.1846^{*}$ \\
\hline & $(1.33)$ & $(1.94)$ \\
\hline \multirow[t]{2}{*}{ Hispanic } & $0.6079 * * *$ & $0.5560 * * *$ \\
\hline & (10.93) & (7.57) \\
\hline \multirow[t]{2}{*}{ Not born in U.S. } & $0.2196 * * *$ & $0.2872 * * *$ \\
\hline & $(4.60)$ & $(4.97)$ \\
\hline \multirow[t]{2}{*}{ Missing where born } & $0.5971 * * *$ & $-10.0140 * * *$ \\
\hline & $(3.44)$ & $(34.05)$ \\
\hline Pseudo R-squared & 0.141 & 0.164 \\
\hline Observations & 8288 & 7025 \\
\hline
\end{tabular}




\section{References}

Alva, S., Coe, N., \& Webb, A. (2010). The Impact of a DROP Program on the Age of Retirement and Employer Pension Costs. Boston College Center for Retirement Research Working Paper.

Brown, K. (2009). The Link between Pensions and Retirement Timing: Lessons from California Teachers.Unpublished manuscript.

Cawley, J., \& Burkhauser, R. (2006). Beyond BMI: The Value of More Accurate Measures of Fatness and Obesity in Social Science Research. NBER working paper, 12291.

Christakis, N. A., \& Allison, P. D. (2006). Mortality after the hospitalization of a spouse. $N$ Engl J Med, 354(7), 719-730.

Coile, C. (2004a, September). Health Shocks and Couples' Labor Supply Decisions. NBER Working Paper Series, 10810, 1-32.

Coile, C. (2004b). Retirement Incentives and Couples' Retirement Decisions. Topics in Economic Analysis and Policy, 4(1), 1-28.

Coile, C., \& Gruber, J. (2007). Future Social Security Entitlements and the Retirement Decision. The Review of Economics and Statistics, 89(2), 234-246.

Erdogan-Ciftci, E., Van Doorslaer, E., \& Lopez-Nicolas, A. (2008). Health, Financial Incentives and Retirement in Spain Tinbergen Institute Discussion Paper, No. 08-093/3.

Friedberg, L., \& Webb, A. (2005). Retirement and the Evolution of Pension Structure. Journal of Human Resources, 40(2), 281-308.

Gilleskie, D., \& Blau, D. (2006). Health insurance and retirement of married couples. Journal of Applied Econometrics, 21(7), 935-953.

Gruber, J., \& Madrian, B. (2002). Health Insurance, Labor Supply, and Job Mobility: A Critical Review of the Literature. NBER Working Papers, National Bureau of Economic Research, Inc., 8817.

Gustman, A., \& Steinmeirer, T. L. (2000). Retirement in Dual Career Families: A Structural Model. Journal of Labor Economics, 18(3), 503-545.

Honig. (1998). Married Women's Retirement Expectations: Do Pensions and Social Security Matter? American Economic Review, 88, 202-206.

Hurd, M. D. (1990). The joint retirement decision of husbands and wives. In D. A. Wise (Ed.), Issues in the Economics of Aging (pp. 231-254). Chicago and London: The University Press.

Johnson, R., \& Favreault, M. (2001, March). Retiring Together or Working Alone: The Impact of Spousal Employment and Disability on Retirement Decisions. The Urban Institute, ??

Krueger, A. B., \& Pischke, J.-S. (1992). The Effect of Social Security on Labor Supply: A Cohort Analysis of the Notch Generation. Journal of Labor Economics, 412-437.

Maestas, N. (2001). Labor, Love and Leisure: Complementarity and the Timing of Retirement by Working Couples. UC Berkeley, Berkeley.

McClellan, M. (1998). Health Events, Health Insurance, and Labor Supply: Evidence from the Health and Retirement Survey. In D. A. Wise (Ed.), Frontiers in the Economics of Aging. Chicago: University of Chicago Press.

McGarry, K. (2004). Health and Retirement: Do changes in health affect retirement expectations? Journal of Human Resources, 39(3), 624-648. 
Munnell, A., \& Soto, M. (2007). When should women claim social security benefits? Journal of Financial Planning, 58-65.

Munnell, A. H., Sass, S., \& Eschtruth, A. (2009). The Social Security Fix-It Book Chestnut Hill: Center for Retirement Research at Boston College.

Ostbye, T., Dement, J. M., \& Krause, K. M. (2007). Obesity and workers' compensation: results from the Duke Health and Safety Surveillance System. Arch Intern Med, 167(8), 766773.

Ruhm, C. (1990). Bridge Jobs and Partial Retirement. Journal of Labor Economics, 8(4), 482501.

Samwick, A. (1998). New Evidence on Pensions, Social Secuirty, and the Timing of Retirement. Journal of Public Economics, 70, 207-236.

Stewart, W. F., Ricci, J. A., Chee, E., Morganstein, D., \& Lipton, R. (2003). Lost productive time and cost due to common pain conditions in the US workforce. Jama, 290(18), 24432454.

Stock, J., \& Wise, D. (1990). The Pension Inducement to Retire: An Option Value Analysis. In D. A. Wise (Ed.), Issues in the Economics of Aging. Chicago and London: University of Chicago Press.

Stock, J., \& Wise, D. A. (1990). Pensions, the Option Value of Work, and Retirement. Econometrica, 58, 1151-1180.

Van Houtven, C. H., Taylor, D. H., Jr., Steinhauser, K., \& Tulsky, J. A. (2009). Is a home-care network necessary to access the Medicare hospice benefit? J Palliat Med, 12(8), 687-694. 


\section{RECENT WORKING PAPERS FROM THE CENTER FOR RETIREMENT RESEARCH AT BOSTON COLLEGE}

Incorporating Employee Heterogenity Into Default Rules for Retirement Plan Selection Gopi Shah Godi and Colleen Flaherty Manchester, May 2010

Accurately Measuring Health Over the Life Course

Fabian Lange and Doug McKee, May 2010

Getting to the Top of Mind: How Reminders Increase Saving Dean Karlan, Margaret McConnell, Sendhil Mullainathan, and Jonathan Zinman, April 2010

The Shrinking Tax Preference for Pension Savings: An Analysis of Income Tax Changes, 1985-2007

Gary Burtless and Eric Toder, March 2010

Social Security, Benefit Claiming and Labor Force Participation: A Quantitative General Equilibrium Approach

Selahattin Imrohoroğlu and Sagiri Kitao, March 2010

How Much Is Enough? The Distribution of Lifetime Health Care Costs

Anthony Webb and Natalia Zhivan, February 2010

Impact of Immigration on the Distribution of American Well-Being

Gary Burtless, December 2009

Actual and Anticipated Inheritance Receipts

Norma B. Coe and Anthony Webb, December 2009

Will Automatic Enrollment Reduce Employer Contributions to 401(k) Plans

Mauricio Soto and Barbara A. Butrica, December 2009

How Seniors Change Their Asset Holdings During Retirement

Karen Smith, Mauricio Soto, and Rudolph G. Penner, December 2009

Retirement Security and the Stock Market Crash: What Are the Possible Outcomes?

Barbara A. Butrica, Karen E. Smith, and Eric J. Toder, November 2009

Fees and Trading Costs of Equity Mutual Funds in 401(k) Plans and Potential Savings from ETFs and Commingled Trusts

Richard W. Kopcke, Francis Vitagliano, and Zhenya S. Karamcheva, November 2009

All working papers are available on the Center for Retirement Research website (http://crr.bc.edu) and can be requested by e-mail (crr@bc.edu) or phone (617-552-1762). 